\title{
Alaska Coastal Mapping Gaps \& Priorities
}

for the assessment of coastal flood \& erosion hazards

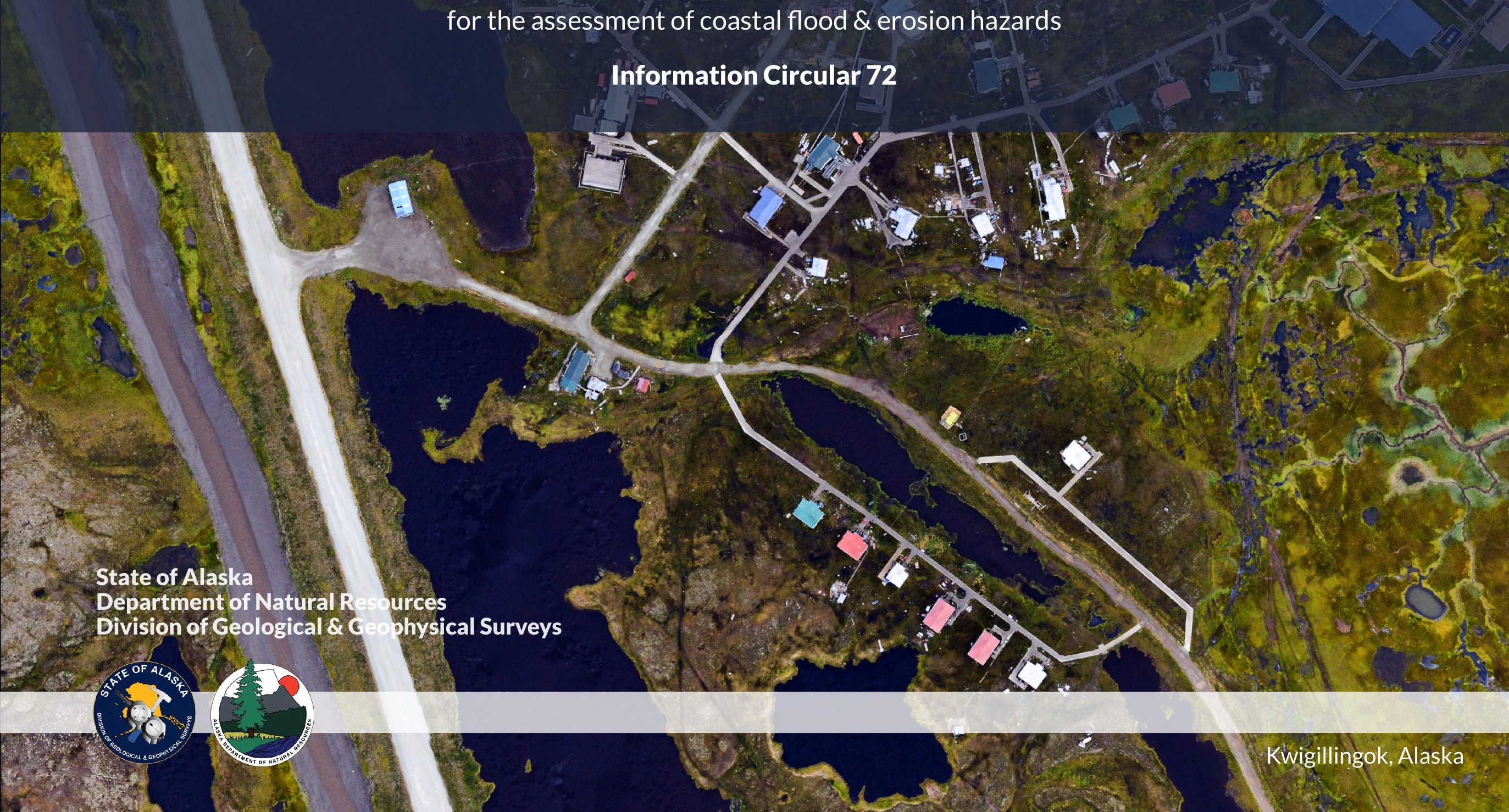




\title{
STATE OF ALASKA
}

Bill Walker, Governor

\section{DEPARTMENT OF NATURAL RESOURCES}

Andrew T. Mack, Commissioner

\section{DIVISION OF GEOLOGICAL \& GEOPHYSICAL SURVEYS}

Steve Masterman, State Geologist and Director

\author{
Publications produced by the Division of Geological \\ \& Geophysical Surveys (DGGS) are available for free \\ download from the DGGS website (dggs.alaska.gov). \\ Publications on hard-copy or digital media can be \\ examined or purchased in the Fairbanks office:
}

Alaska Division of Geological \& Geophysical Surveys

3354 College Rd., Fairbanks, Alaska 99709-3707

Phone: (907) 451-5010 Fax (907) 451-5050

dggspubs@alaska.gov | dggs.alaska.gov

\section{DGGS publications are also available at:}

Alaska State Library,

Historical Collections \& Talking Book Center

395 Whittier Street

Juneau, Alaska 99811

Alaska Resource Library and Information Services (ARLIS)

3150 C Street, Suite 100

Anchorage, Alaska 99503

\section{Suggested citation:}

Overbeck, J.R., ed., 2018, Alaska coastal mapping gaps \& priorities, Alaska

Division of Geological \& Geophysical Surveys Information Circular 72.

http://doi.org/10.14509/30096

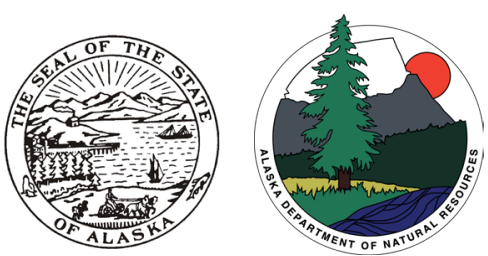




\section{Contents}

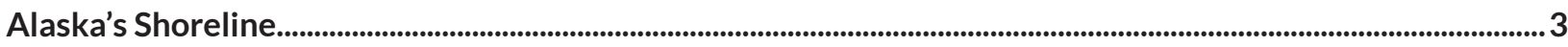

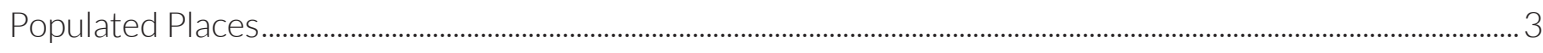

Alaska Native Corporations ..................................................................................................................................................

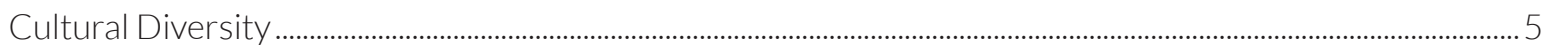

Many Types of Shorelines ......................................................................................................................................................

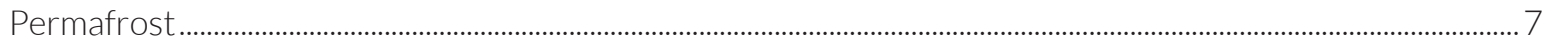

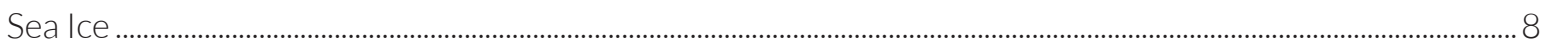

Relative Sea Level Change ........................................................................................................................................................................9

Coastal Hazards ...............................................................................................................................................................................

Baseline Coastal Data .................................................................................................................................................................. 11

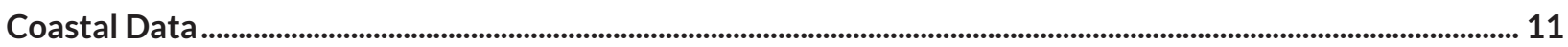

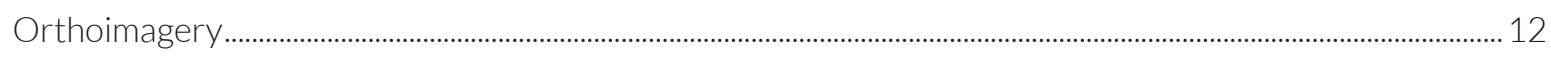

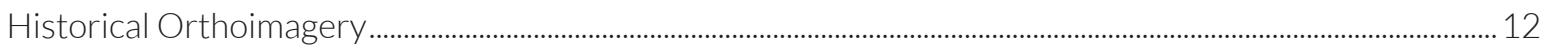

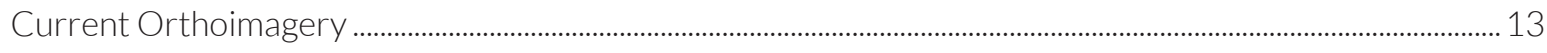

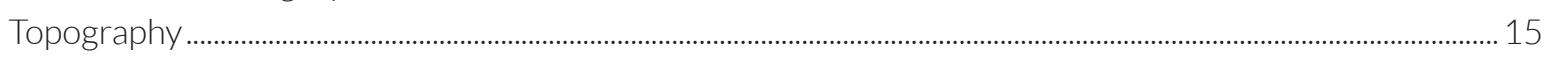

Coastal Elevation Profiles ..................................................................................................................................................................... 17

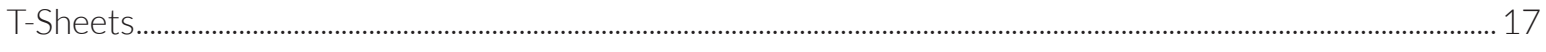

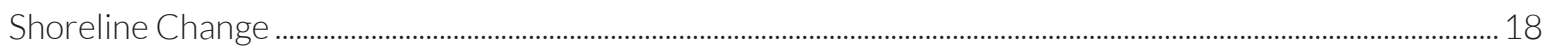

Comparing Geospatial Datasets.......................................................................................................................... 19

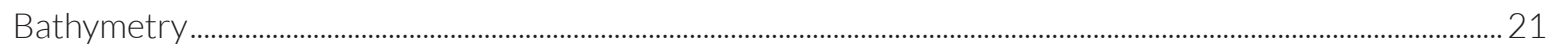

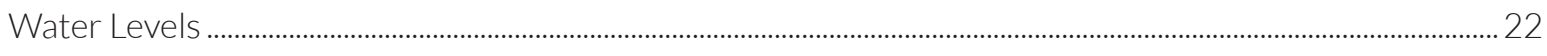

Alaska Water Level Watch .....................................................................................................................................................23

Water Level Models ................................................................................................................................................................2 24

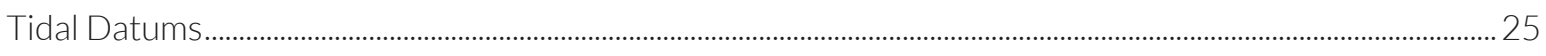

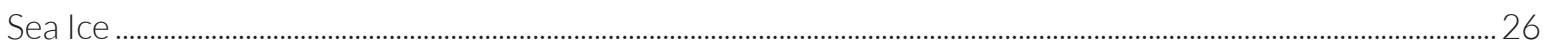

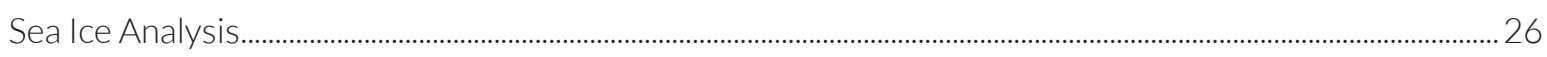

Coupled Sea Ice-Water Level Models .............................................................................................................................2 27

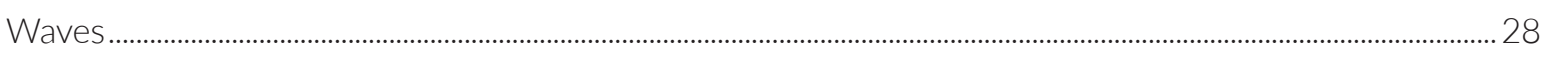

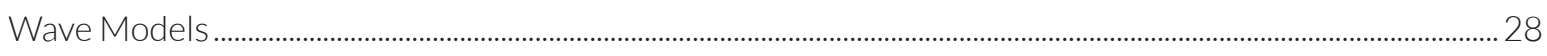

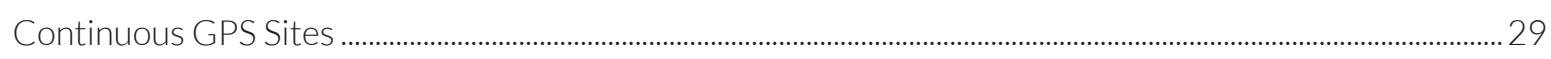

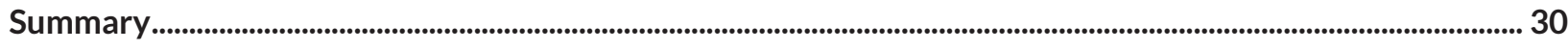

Baseline Data Needs .......................................................................................................................................................

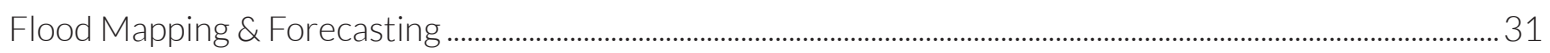

Erosion Mapping \& Forecasting ............................................................................................................................................ 32

Benefits for Alaskans ........................................................................................................................................................................... 33

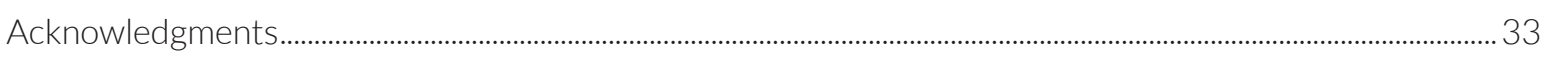

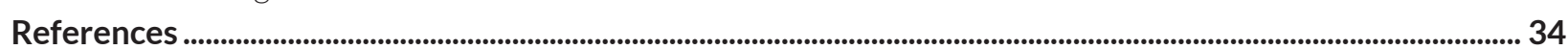





\section{State of Alaska Coastal Hazards Program}

The State of Alaska established the Division of Geological \& Geophysical Surveys (DGGS) to carry out Alaska Statute 41.08.020:

"Determine the potential of Alaskan land for production of metals, minerals, fuels, and geothermal resources, the locations, and supplies of groundwater and construction material, and the potential geologic hazards to buildings, roads, bridges, and other installations and structures."

Within the DGGS mission, the Coastal Hazards Program (CHP) is engaged in ongoing investigations that expand our understanding of how the coastline has evolved and how it will respond to hazardous events and long-term changes. CHP studies focus on the impacts of flooding and erosion on Alaska's coastal communities from coastal storms, sea level rise, permafrost thaw, and changing ocean conditions. The northern and western coasts of Alaska are particularly vulnerable to these hazards. Throughout the document, a greater focus is put on these regions of Alaska. DGGS programs that focus on other coastal hazards (for example: Tsunami) as well as other geographies of Alaska are not covered here.

CHP is dedicated to fostering partnerships that improve the quality and quantity of critical coastal baseline data that are necessary to inform decision making throughout the state. This document is meant to define coastal baseline data, provide guidance on which communities in Alaska still lack baseline data, what data are missing, and the decision-making products to which baseline data can contribute.

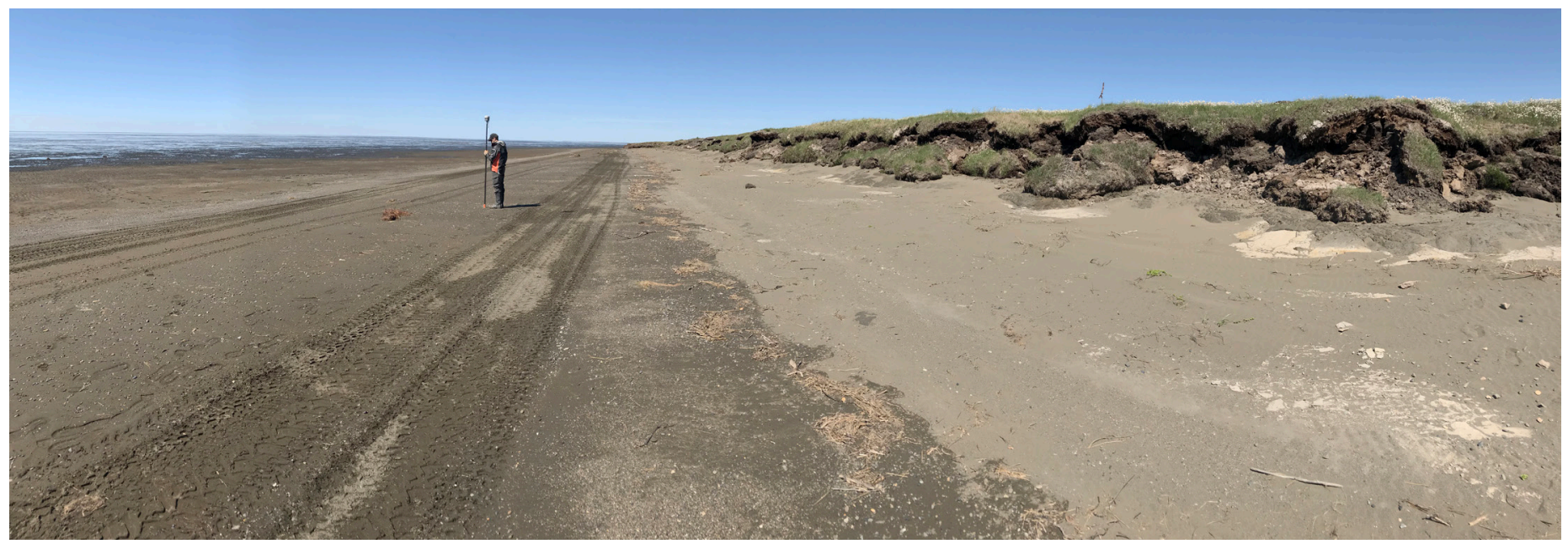





\section{Alaska's Shoreline}

\section{Populated Places}

Alaska's shoreline is diverse in geology, geography, climate, vegetation, wildlife, and culture. For the purpose of this discussion, we divide Alaska's coastal geography into eight regions. Four major water bodies-the Beaufort Sea, Chukchi Sea, Bering Sea, and Gulf of Alaska-border these coastal regions.

Alaska comprises nearly $40 \%$ of tidally-influenced shoreline in the U.S. and $0.5 \%$ of the coastal population. There are 159 communities spread along the 6,640 miles of the Alaska coast.

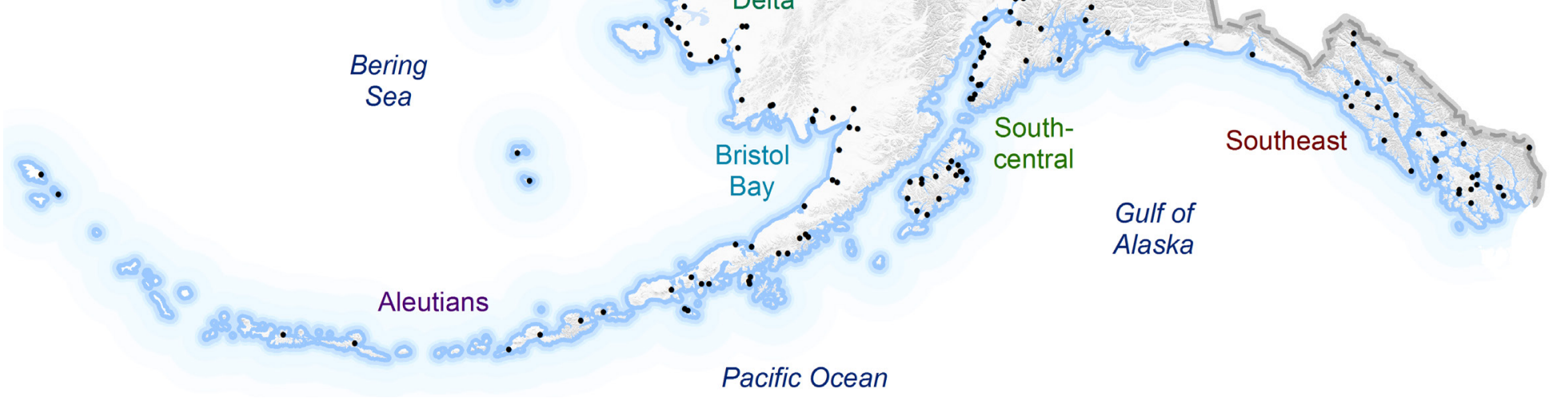




\section{Alaska Native Corporations}

The Alaska Native Claims Settlement Act

(ANCSA) of 1971 established twelve regional

Native corporations in Alaska. A $13^{\text {th }}$ represents

Alaska Natives residing outside Alaska.

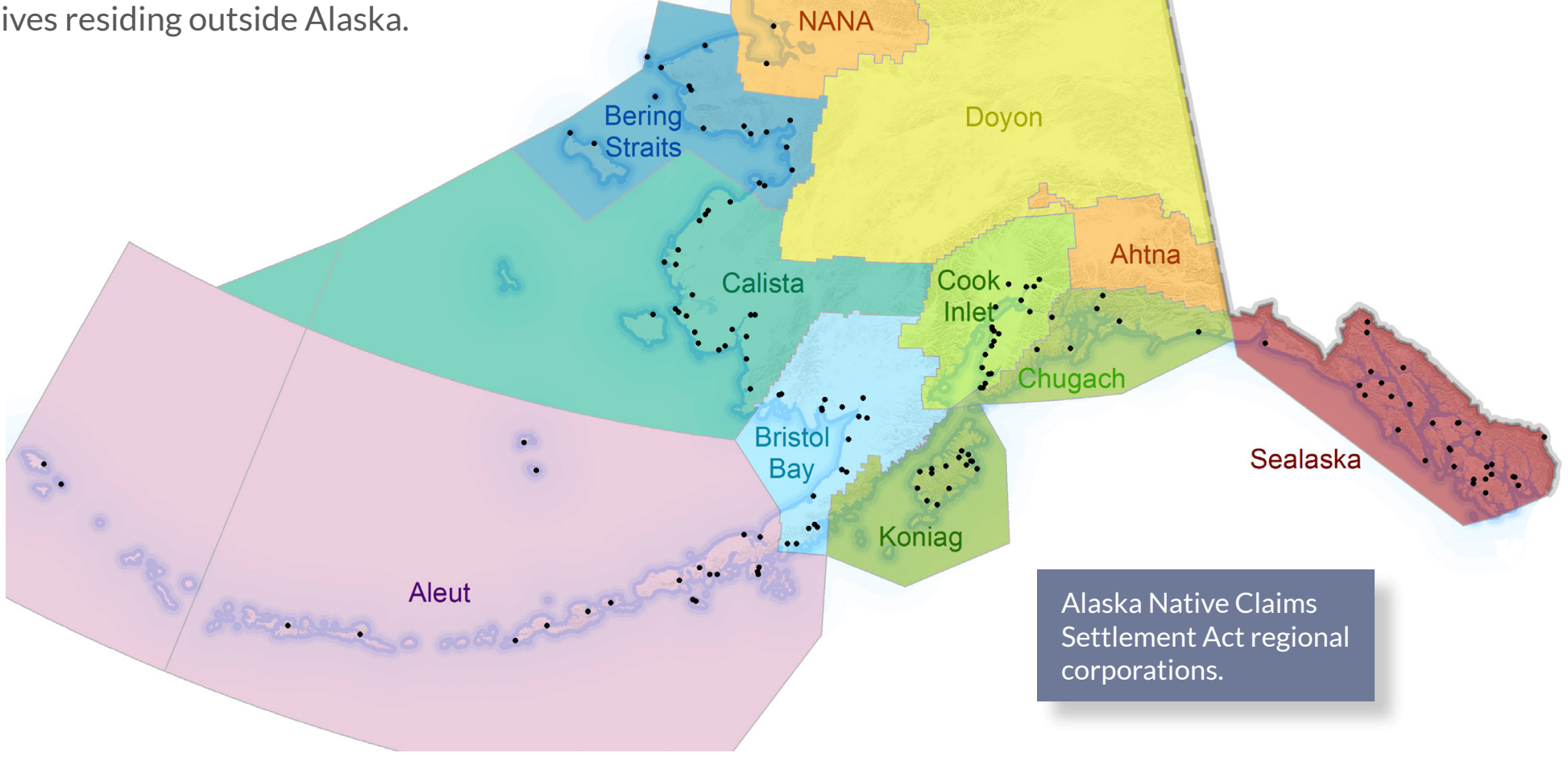




\section{Cultural Diversity}

The regions span a rich traditional cultural and linguistic diversity. Ten of the regional native corporations represent coastal areas, and include the greatest number of communities and largest rural population.

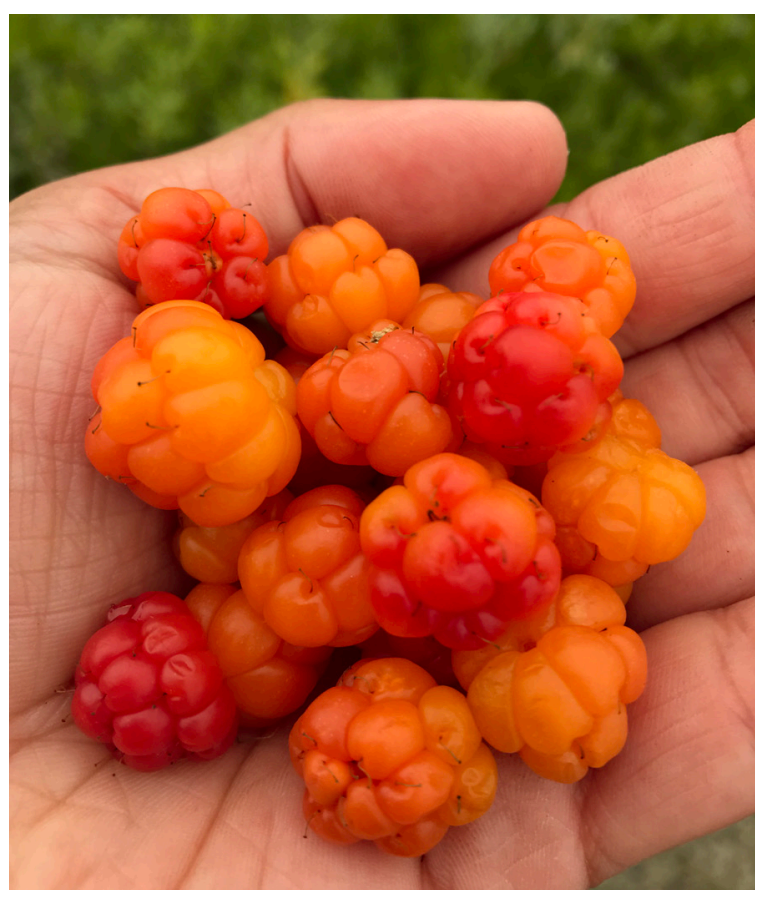

Salmonberries near Kotzebue

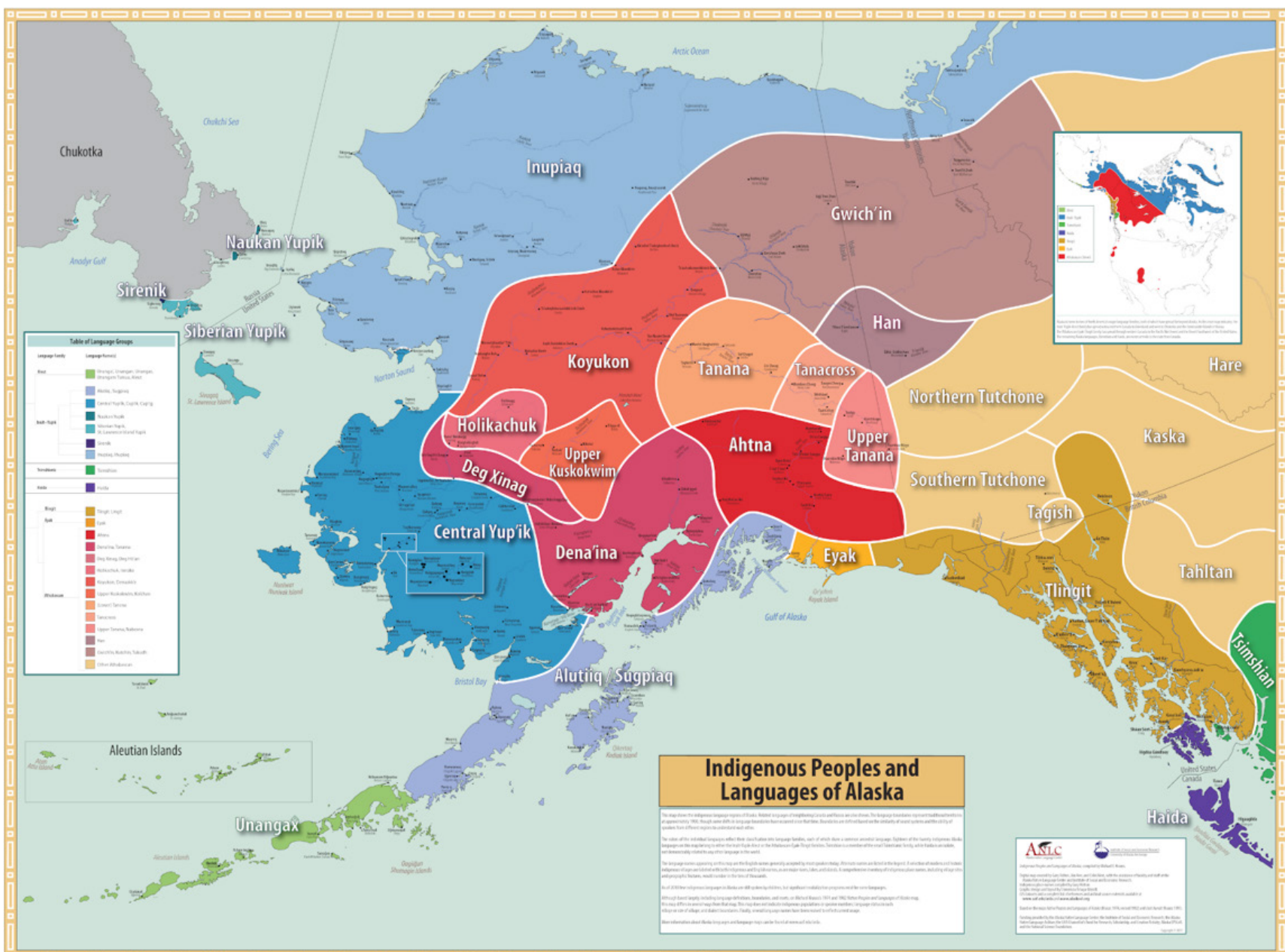

Map of indigenous peoples and languages of Alaska (Krauss and others, 2011). 
Shoreline Type

Ground ice slumps \& Inundated tundra Lagoon, organics, mudflat, peat

Sand or Gravel

Rock

- Man-made

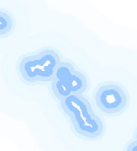

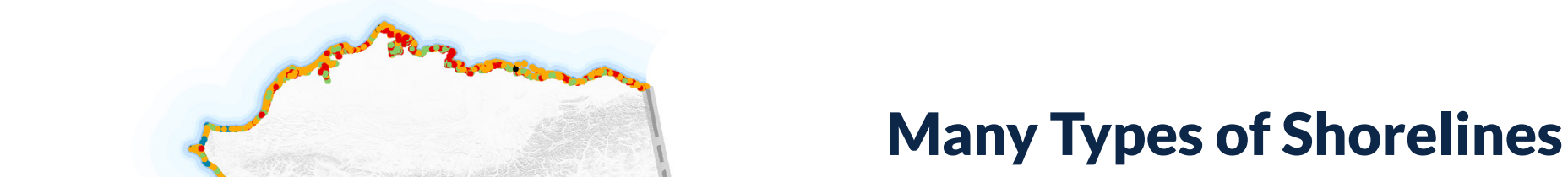

Alaska has a wide variety of shoreline types that are common along the coast of the contiguous U.S., as well as some unique Arctic shorelines. Alaska's cold climate results in permafrost coastlines as well as coastlines seasonally affected by Arctic sea ice.

ShoreZone shoreline types

(Shorezone, 2017). Blue

coastline is undefined. 


\section{Permafrost}

Ground with a temperature that remains below $32^{\circ} \mathrm{F}$ (the freezing point of water) for two or more consecutive years.

Much of Alaska is underlain by permafrost, and it becomes more continuous to the north. Permafrost is vulnerable to rising air and sea temperatures that can thaw ice-rich soils. Much of Alaska's rural infrastructure is built directly on permafrost, which is very strong when frozen but becomes unstable and can subside when thawed.

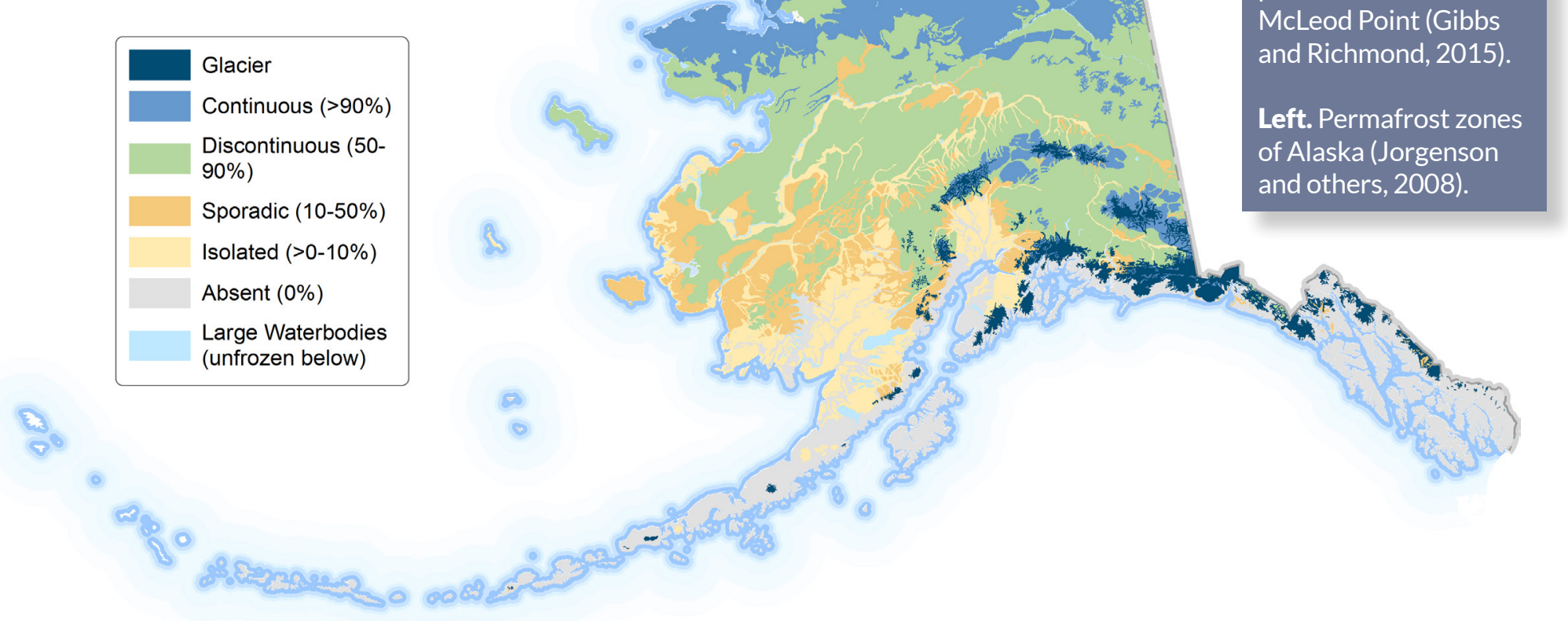

Above. Ice-rich

permafrost bluffs at

McLeod Point (Gibbs

and Richmond, 2015).

Left. Permafrost zones of Alaska (Jorgenson

and others, 2008).

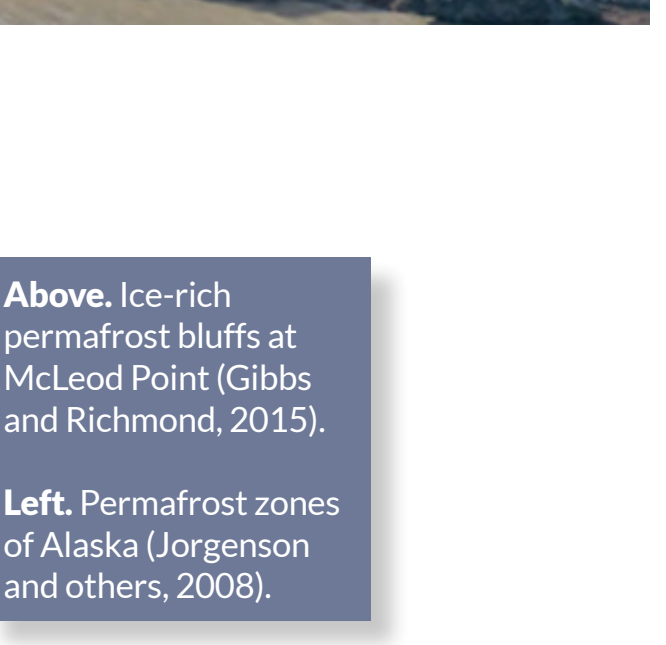




\section{Sea Ice}

Sea ice forms offshore of Alaska's northern and western coasts in winter, creating extreme seasonal differences in ocean conditions. Sea ice can dampen ocean conditions-such as wind-driven waves, currents, and storm surge-that cause coastal erosion and flooding. In recent years, however, the extent and thickness of sea ice during the fall storm season has been at record lows.

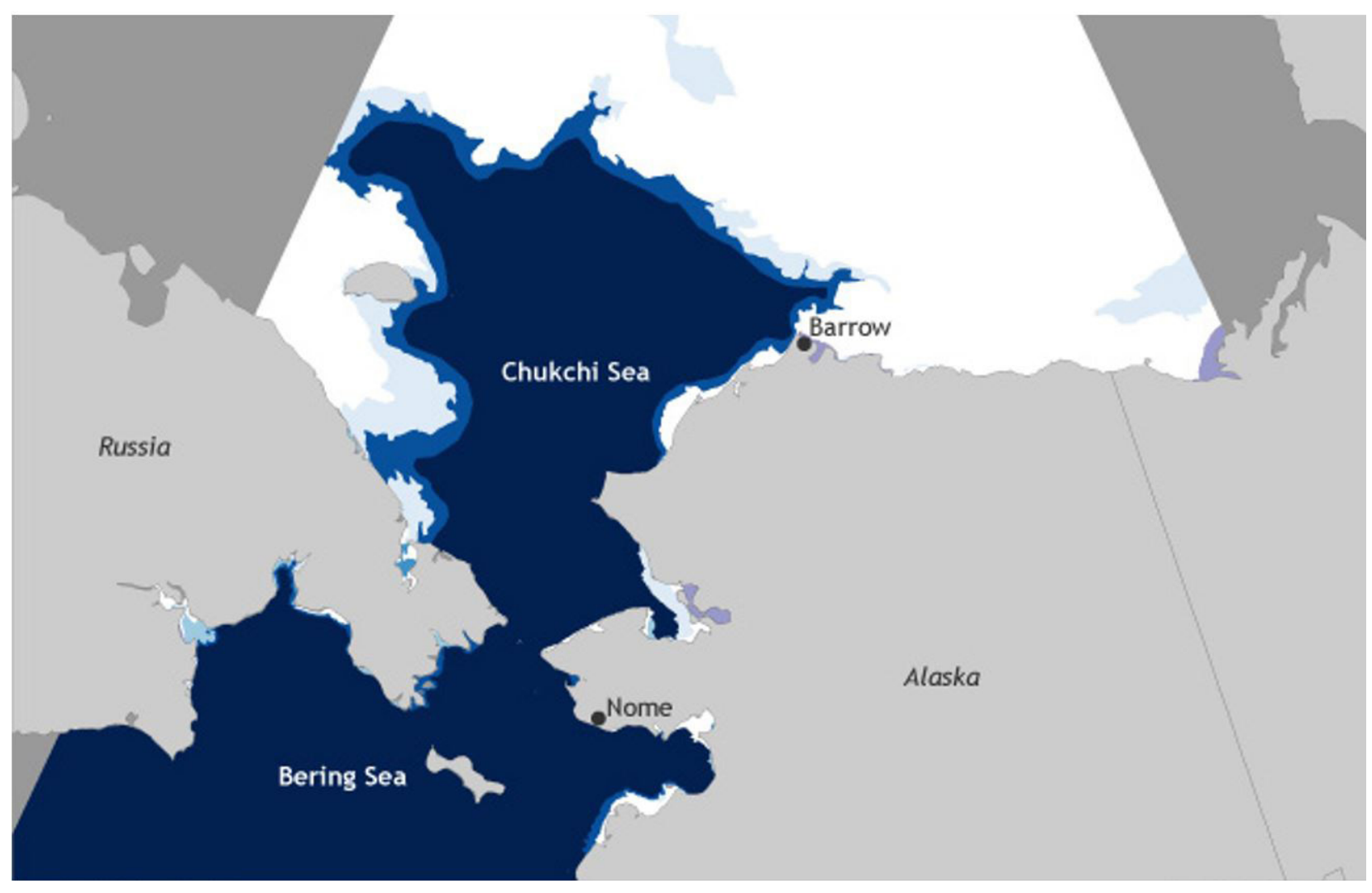

November 19, 2017 Sea ice concentration (percent covered)

NOAA Climate.gov Data: NWS ASIP
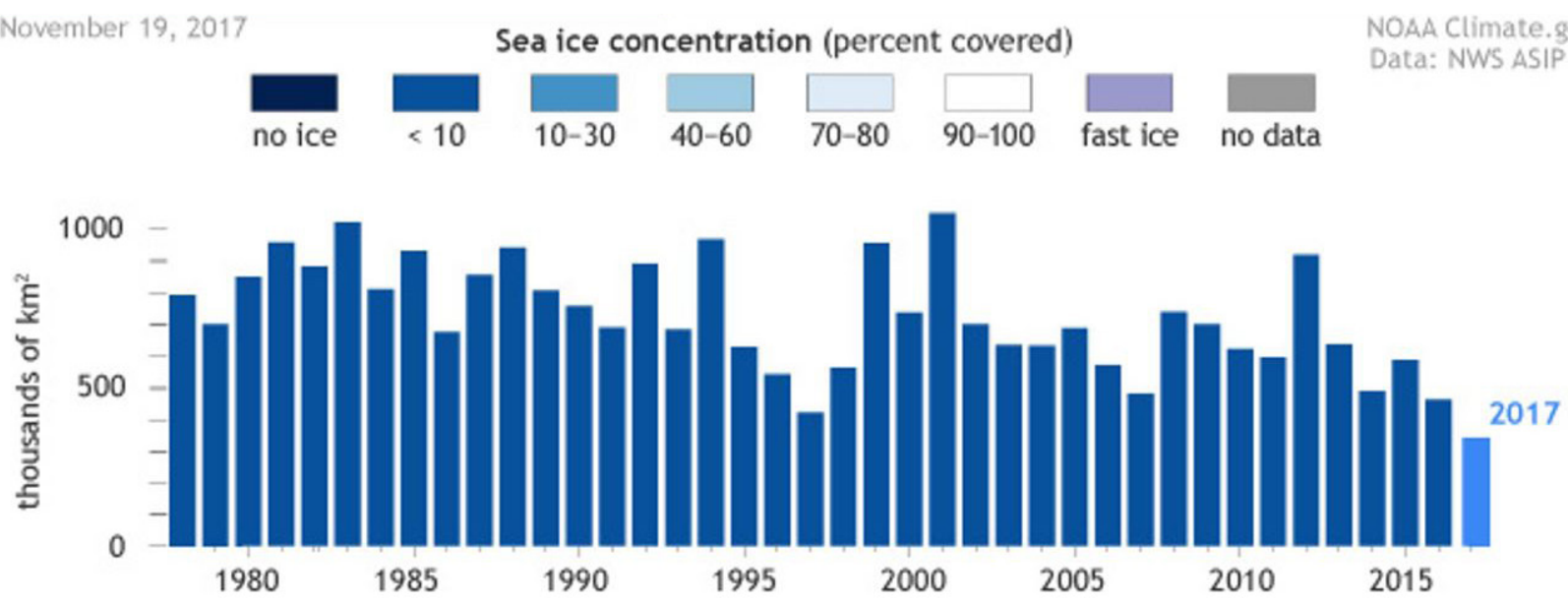

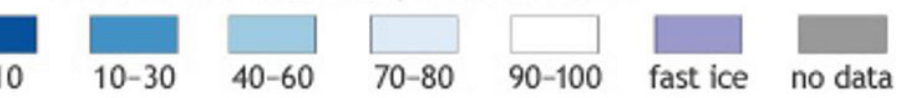

The bar chart demonstrates the 2017 record low Arctic sea ice extent in Alaska's Bering and Chukchi seas. The map shows sea ice extent on November 19, 2017. Figures from Thoman (2017) at www.climate.gov. 


\section{Relative Sea Level Change}

The combined vertical motion of land and sea level,

resulting in inundation or exposure of the coast.

Sea levels are falling relative to the land in some regions of Alaska where uplift of the land is outpacing global sea level rise. In Southeast Alaska, isostatic rebound-the rising of land masses that were depressed by the huge weight of ice sheets during the last glacial period-is lifting the coast out of the water. Other regions in Alaska are experiencing relative sea level rise from the combined rise in sea level and subsidence of the land, such as on the Yukon-Kuskokwim Delta.
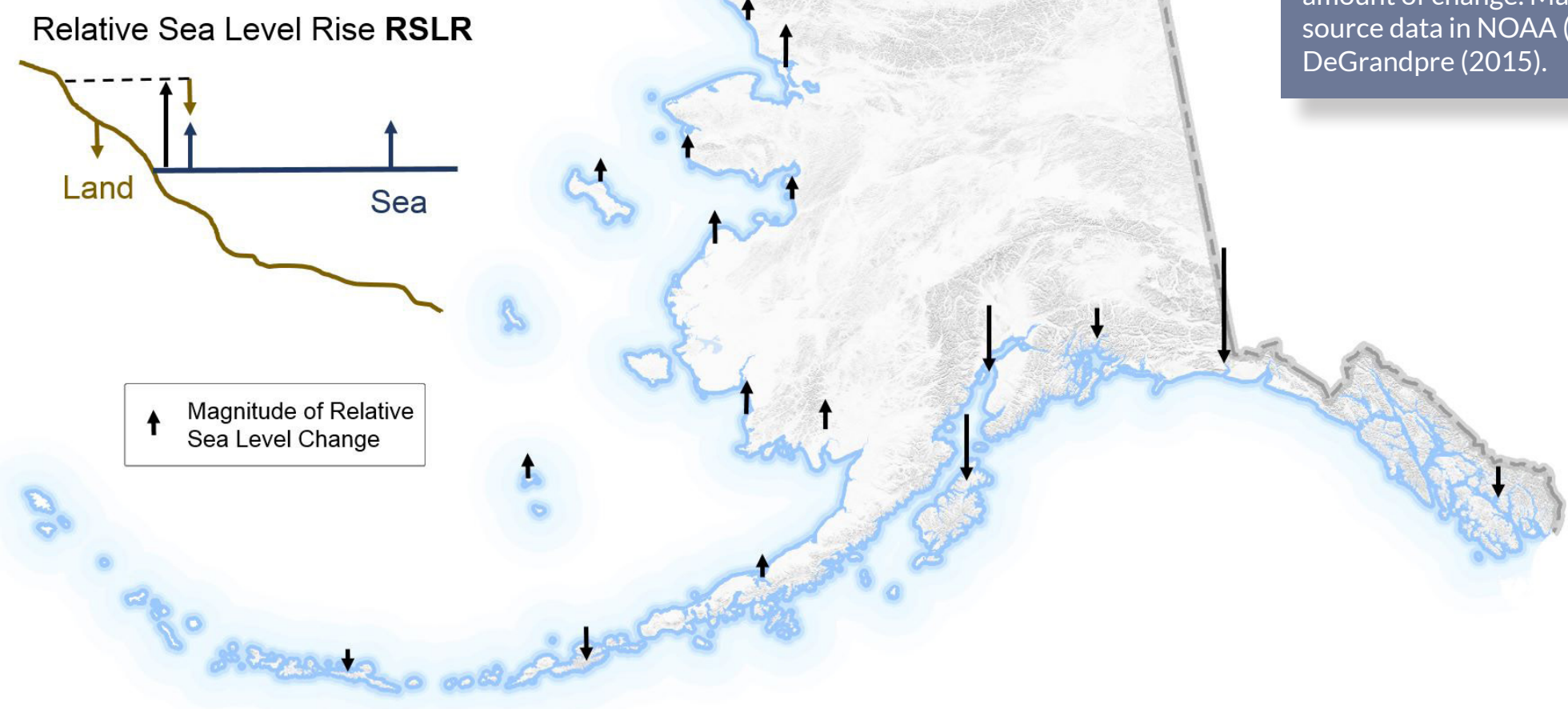

Map of relative sea level change in Alaska. Arrows show the direction and magnitude of changes, with longer arrows indicating greater amount of change. Map created from source data in NOAA (2017f) and DeGrandpre (2015). 


\section{Coastal Hazards}

Coastal flooding and erosion resulting from naturally occurring coastal processes, changes in ocean conditions from reduced sea ice during fall and winter storm seasons, thawing coastal permafrost, and relative sea level rise impact coastal infrastructure and cultural resources of Alaska Native communities and other installations.

\begin{tabular}{|r|c|c|c|}
\hline \multirow{2}{*}{$\begin{array}{c}\text { Vulerability } \\
\text { Type }\end{array}$} & \multicolumn{3}{|c|}{ Coast Type } \\
\cline { 2 - 4 } Exposed & Sheltered & Riverine \\
\hline Possible Erosion & $\odot$ & $\bullet$ & 4 \\
\hline Erosion & $\bullet$ & & $\mathbf{\Delta}$ \\
\hline Erosion and Flooding & $\bullet$ & $\mathbf{D}$ & $\mathbf{\Delta}$ \\
\hline $\begin{array}{r}\text { Flooding and } \\
\text { Possible Erosion }\end{array}$ & $\bullet$ & $\mathbf{D}$ & $\mathbf{\Delta}$ \\
\hline Flooding & $\bullet$ & - & $\mathbf{\Delta}$ \\
\hline
\end{tabular}
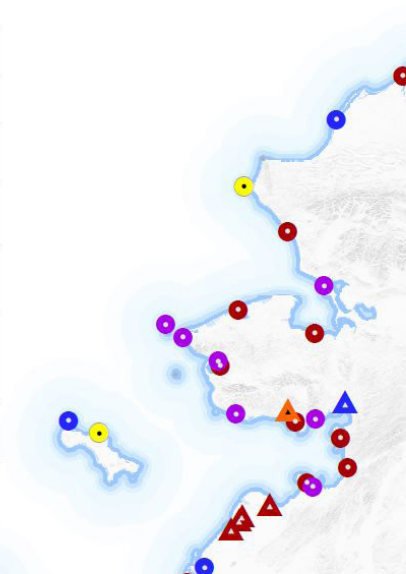

- 2

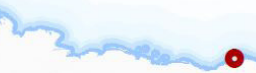

L

$\propto$

.
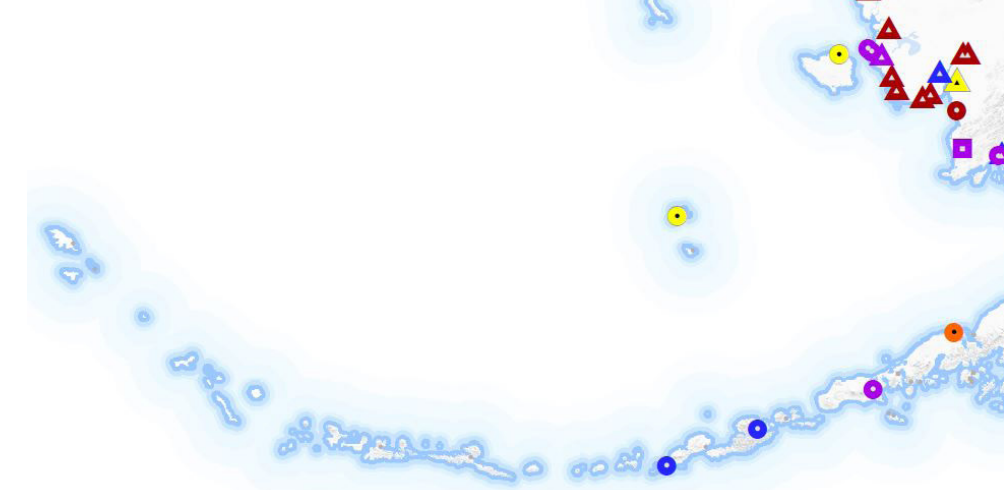
-

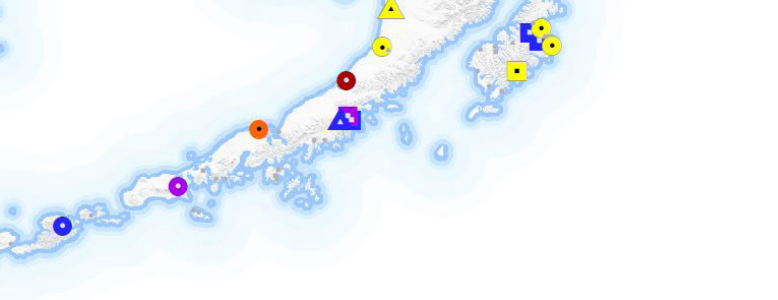

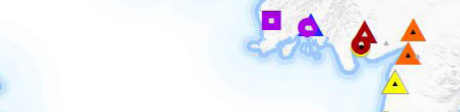

Coastal communities and

installations subject to flood and/or erosion hazards (GAO, 2003; GAO, 2009; USACE, 2009; IAWG, 2009). Symbol shape represents the coastal setting (exposed, sheltered, or riverine) and color identifies whether a community is subject to, or possibly subject to, flooding and/or erosion.

Black symbols show locations that have not been identified as subject to flooding and/or erosion. 


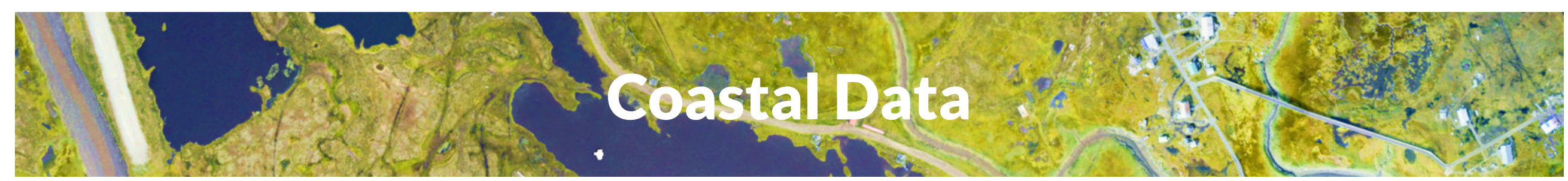

\section{Baseline Coastal Data}

In order to assess Alaska's coastal erosion and flooding hazards, major gaps in baseline coastal data must be filled. Progress has been made over the last several years, but the extensive shoreline and rapidly changing environment require that these datasets not only be collected for the first time but also be updated or continually monitored. The main data types used for assessing coastal flood and erosion hazards listed to the right are summarized in the following pages.

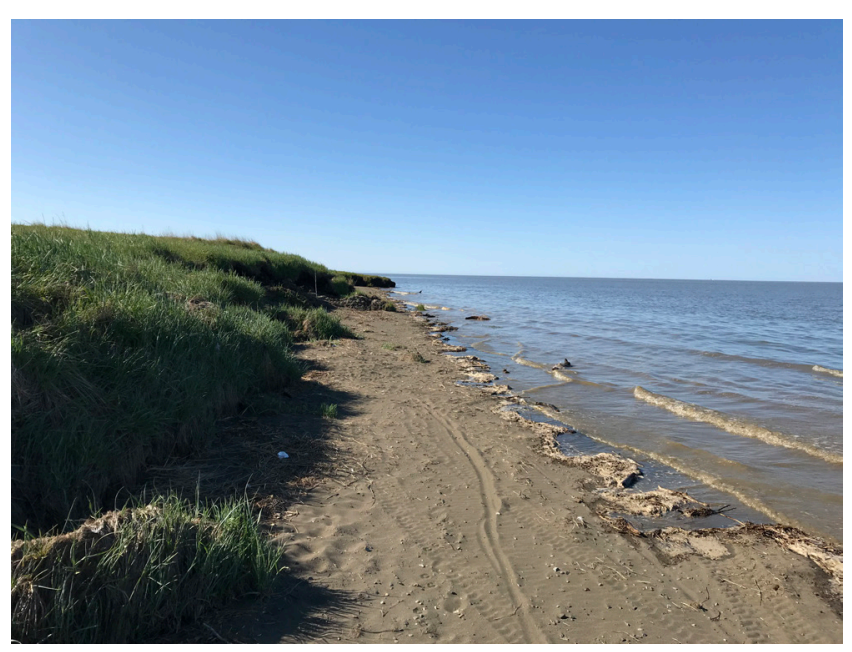

High tide at Quinhagak

\section{Orthoimagery}

Topography

Bathymetry

Water Levels

Sea Ice

Waves

Continually Operating Reference Systems (CORS) 


\section{Coastal Data}

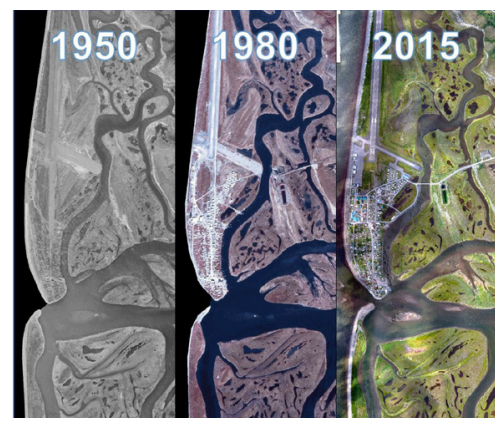

Orthoimagery of Unalakleet from 1950, 1980, and 2015 used to delineate shoreline positions

through time and project potential future shoreline positions.

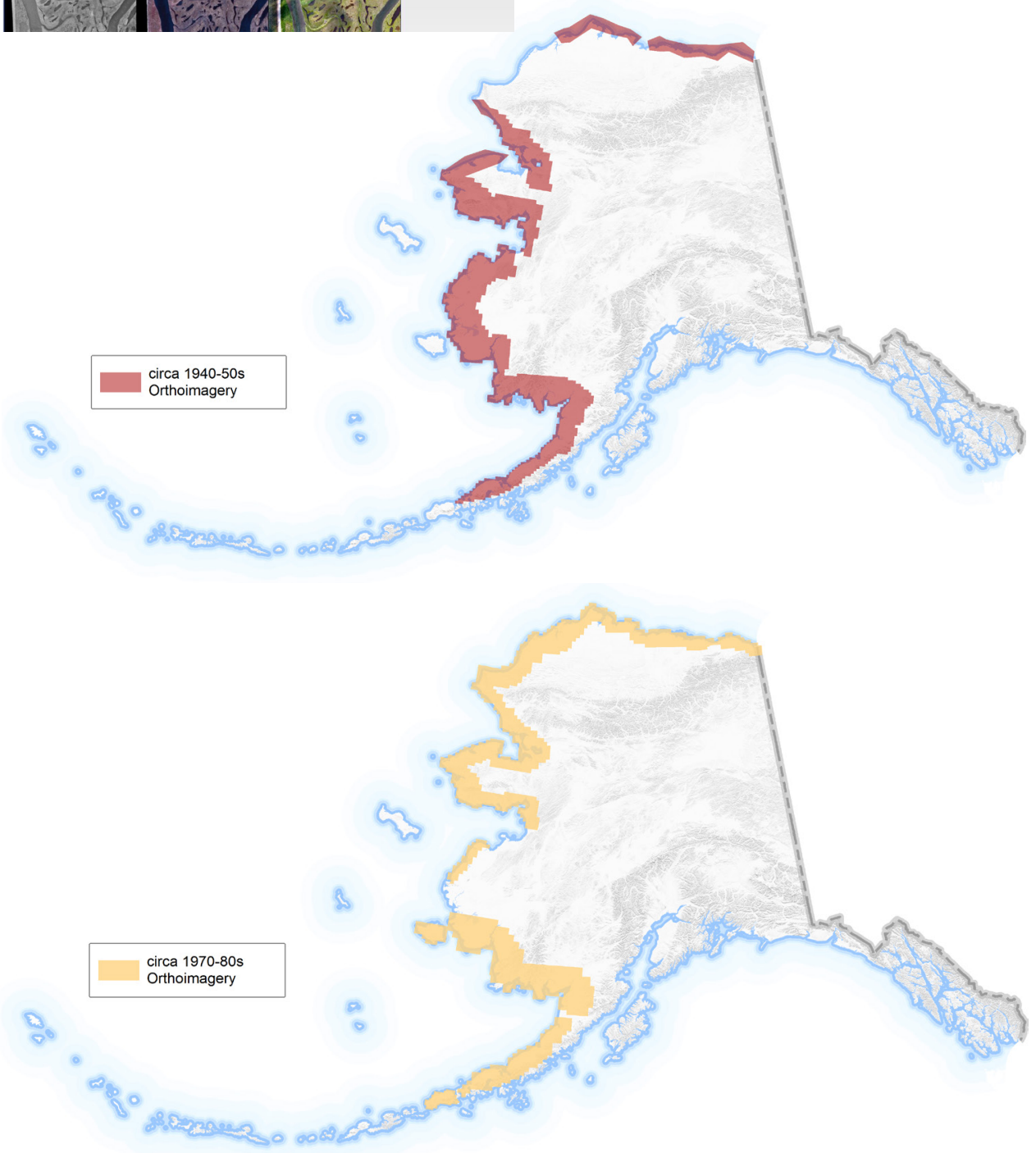

\section{Orthoimagery}

Aerial photographs or satellite images that have been geometrically corrected ("orthorectified") to fit the earth's irregular surface such that the scale is uniform and the image has the same lack of distortion as a map.

Orthoimagery can be used to identify and delineate changing shoreline positions through time. From these datasets, rates of shoreline change are calculated and shoreline positions projected for future dates. Projected shorelines can show areas where infrastructure and economically valuable land may be at risk of future erosion.

\section{Historical Orthoimagery}

Aerial photographs were collected over most of Alaska during the 1940s-1950s and 1970s-1980s for the purpose of creating topographic maps. These film images have been scanned to make digital images, but most of them have not been orthorectified. Several large swaths of coast have been orthorectified in recent years. Areas of Alaska that have historical imagery but have not been orthorectified, may require further ground control points to ensure the accuracy of the data.

Ground control point (GCP) - points on the surface of the earth with precisely known locations used to georeference data. Points are either surveyed using global positioning systems (GPS) or can be identified on a different orthoimage (aerial or satellite) that already has an established level of accuracy.

Above. Orthoimagery collected ca. 1940-50's used to determine rates of shoreline change shown in red.

Below. Orthoimagery collected ca. 1970-80's used to determine rates of shoreline change are shown in orange. 


\section{Current Orthoimagery}

Advances in processing digital aerial photographs using "Structurefrom-Motion" (SfM) computer algorithms have lowered the barriers to producing high-resolution orthoimagery.

Small fixed-wing aircraft and drones can be used to collect highresolution aerial imagery, particularly in remote regions of Alaska that have been logistically challenging to reach.

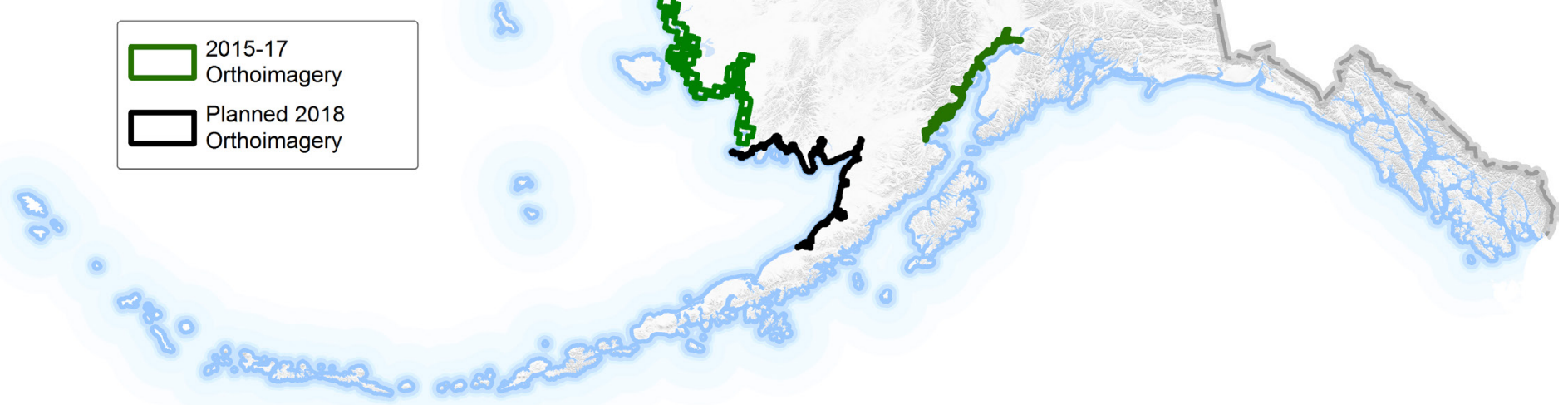

Between 2015 and 2017, the State of Alaska Department of Natural Resources, USGS, and NOAA

undertook major efforts to collect high-resolution orthoimagery along the Alaska coast. The extent of coastal orthoimagery collected in

this campaign is shown in green on the map to the left. In 2018 NOAA's Office for Coastal Management has planned orthoimagery collections at North Slope communities and in Bristol Bay shown in black.

Shorelines have been delineated from portions of these data, and are shown on page 18.

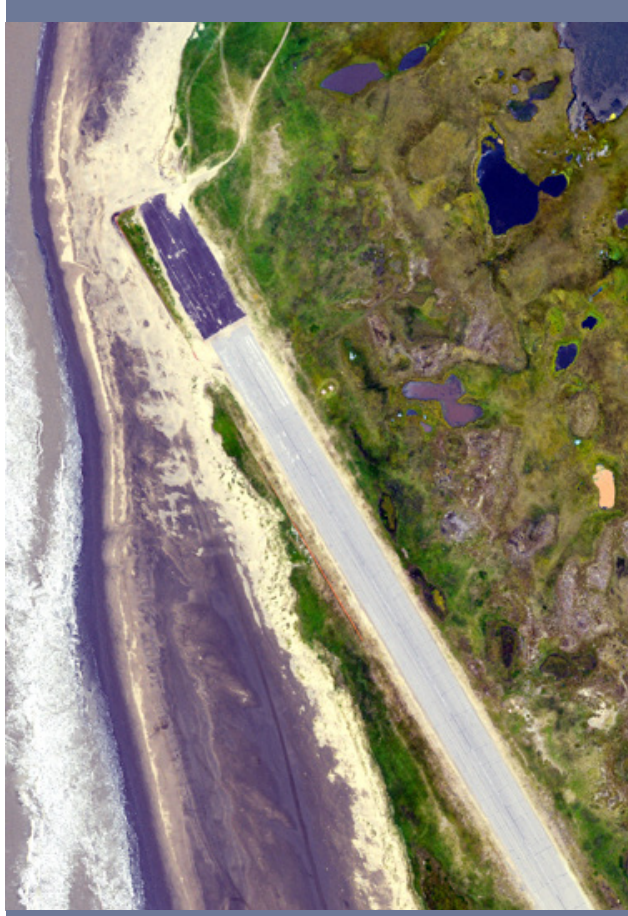

Example of high resolution orthoimagery at Hooper Bay airport, Alaska. 


\title{
Coastal Data
}

\section{Current Orthoimagery}

Orthoimagery can also be obtained from satellites. The lower resolution of many of these datasets is not ideal for detailed coastal mapping, but the imagery can provide important information for coastal management. The State of Alaska is committed to collecting and processing satellite imagery to develop the state's continually-updated "Best Data Layer" (BDL) of orthoimagery.

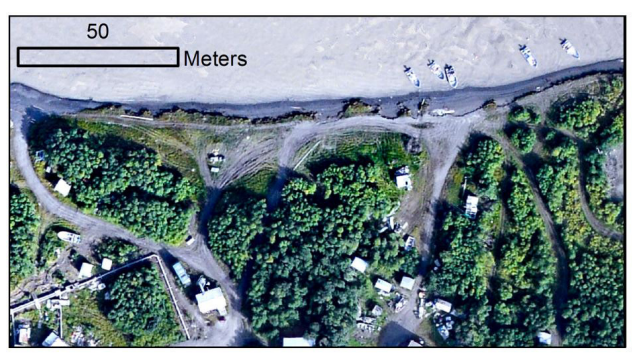

High-resolution,

high-accuracy aerial image

Above. High resolution and highaccuracy aerial image compared to SDMI satellite image at Alakanuk, Alaska.

Right. The completion status of Statewide Digital Mapping Initiative (SDMI) best data layer of orthoimagery. Data are considered complete if they were collected within 5 years of the current date. Nearly 70 percent of the state is currently in need of refreshed data.

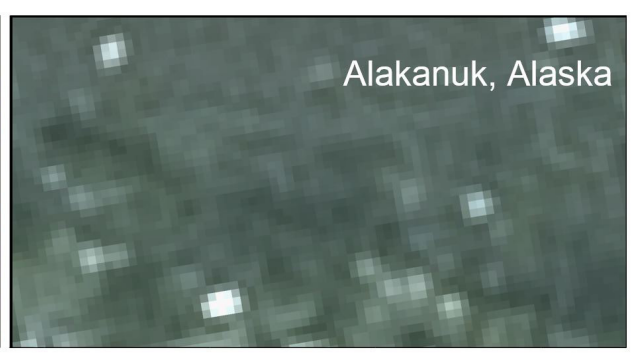

SDMI satellite image

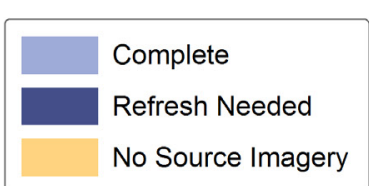

\author{
.
}

(1) 


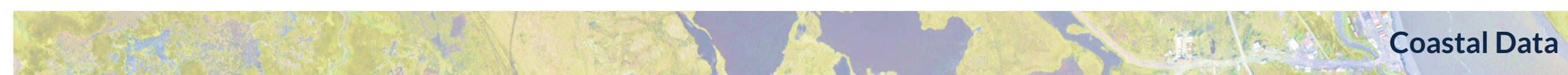

\section{Topography}

\section{Digital Elevation Model (DEM)}

Three-dimensional representation of

the earth's surface created from elevation data.

DEMs are used to determine flood zones, project or forecast flood elevations, define shoreline positions, and as a base for engineering studies or designs. DEMs can be produced using many different sources of elevation data, including aerial and satellite imagery, lidar (light detection and ranging), and ifsar (interferometric synthetic aperture radar).

Each type of data source has advantages and disadvantages. Although different resolutions of coastal elevation data have been collected over Alaska in recent years, not all elevation data can be used to effectively map flooding and erosion.

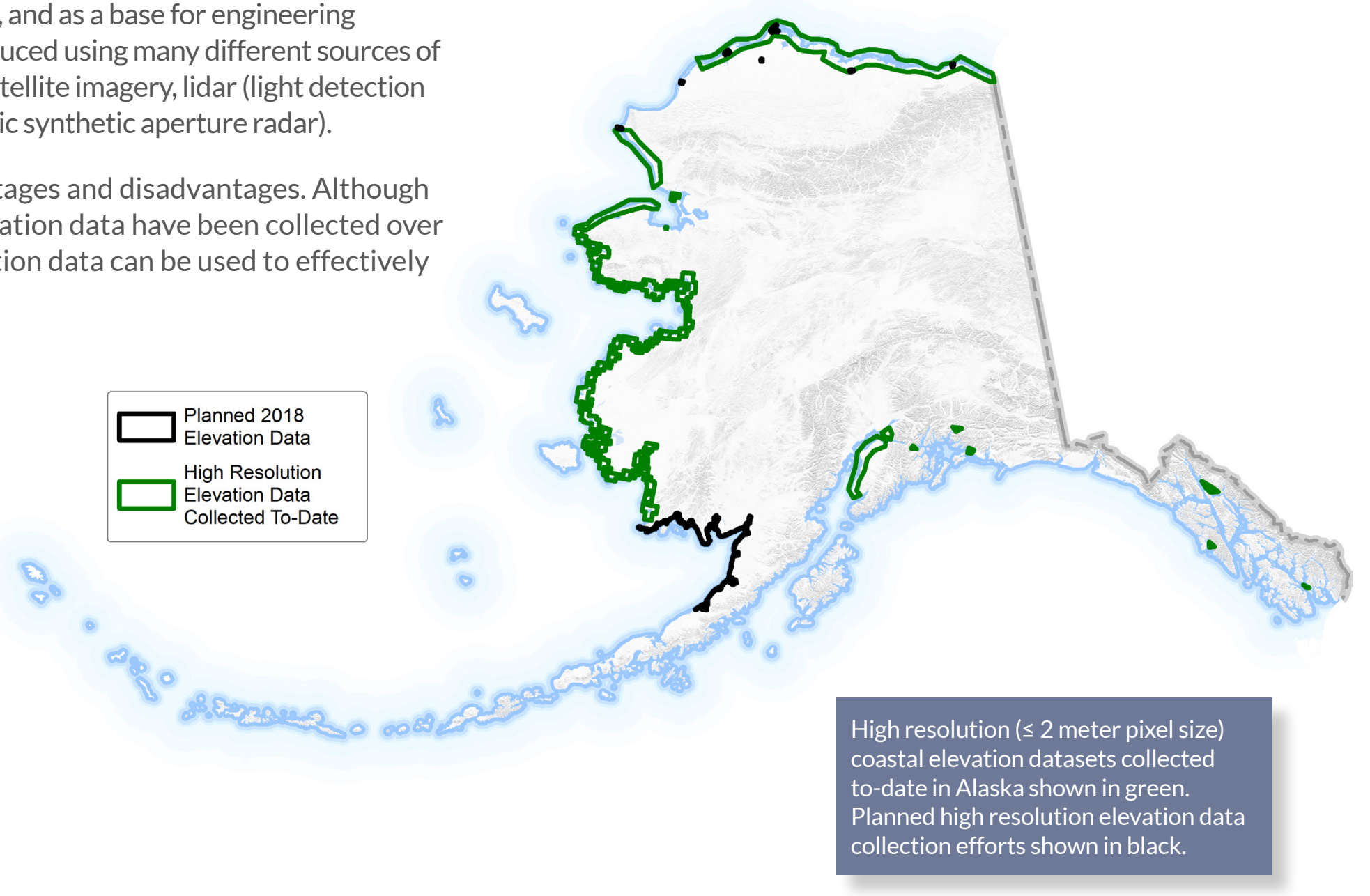




\section{Coastal Data}

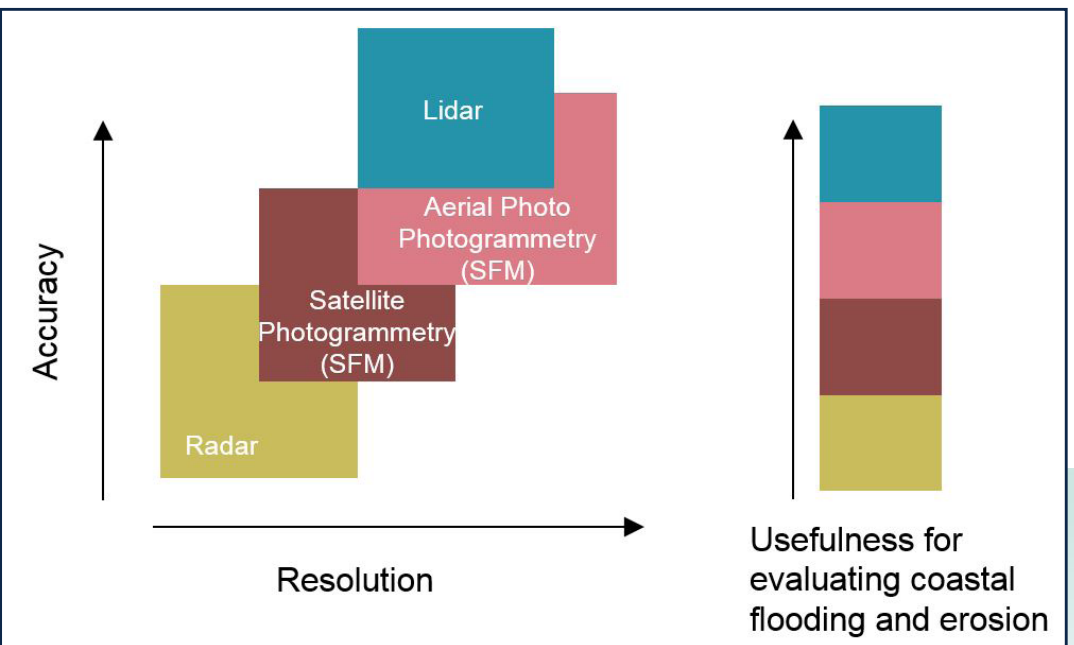

Above. Schematic of elevation data usefulness for evaluating coastal

flooding and erosion by data type.

Right. Schematic of elevation data collection methods and cost created by

Scenarios Network for Alaska + Arctic Planning and DGGS.

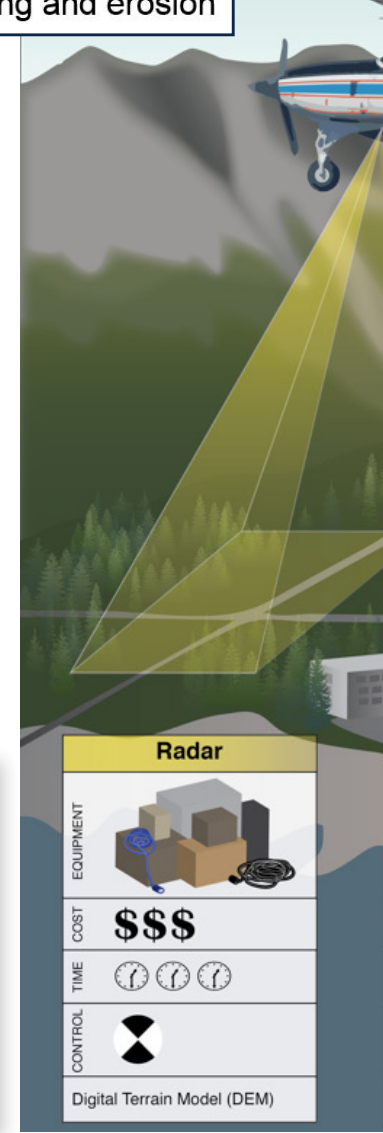

\section{$2 x=000$} व́
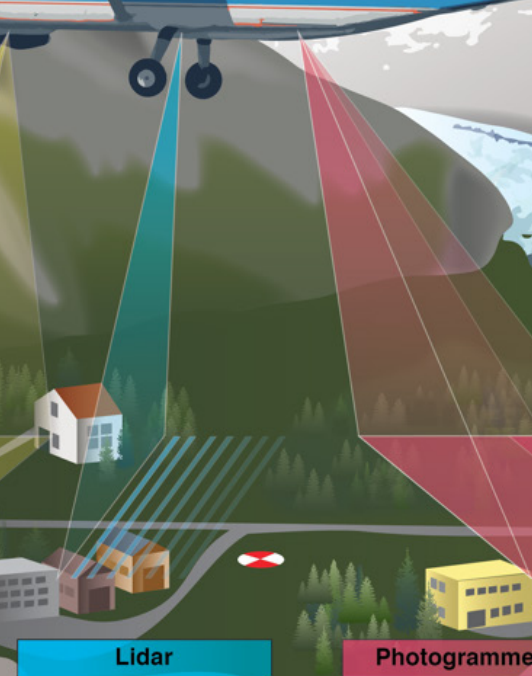

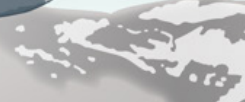
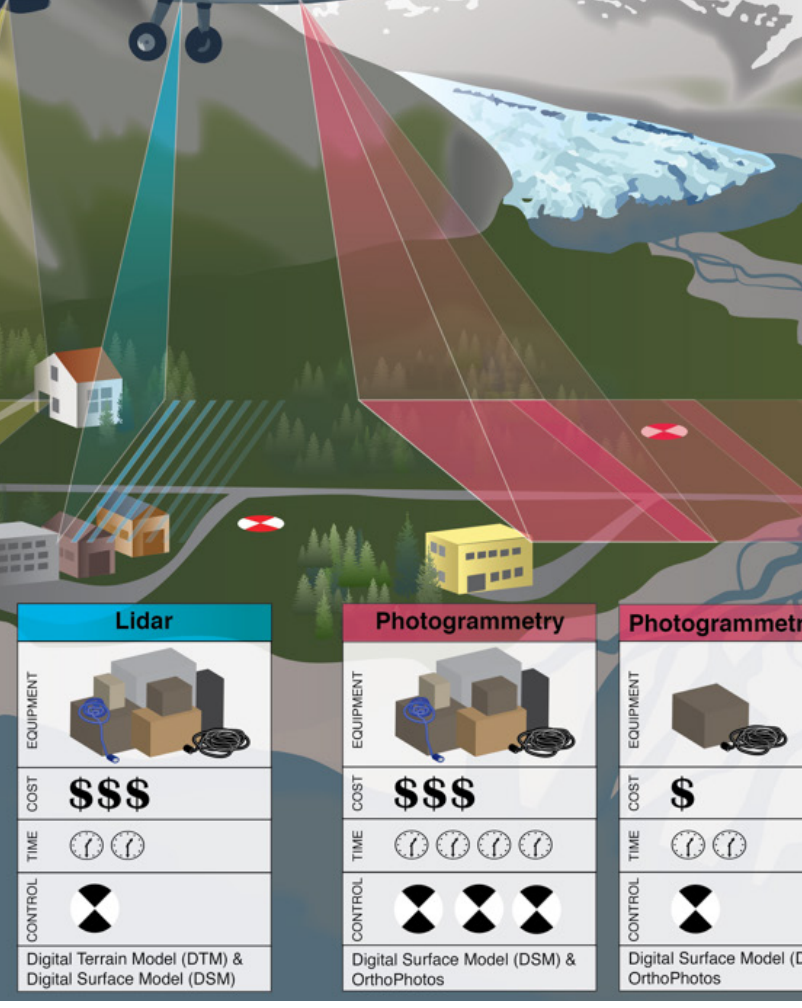

Phommetry (SFM)
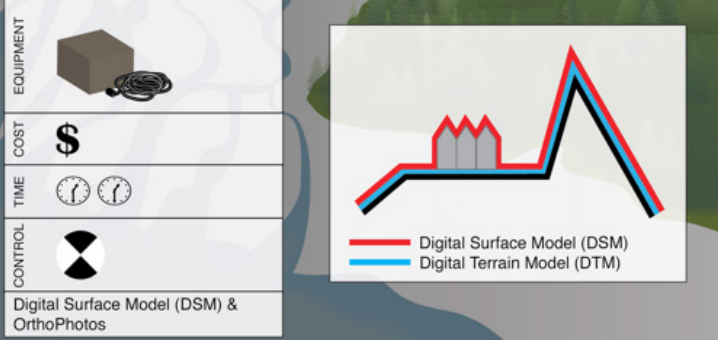

- 16 - 


\section{Coastal Elevation Profiles}

Coastal elevation profiles are collected using survey-grade GPS in cross-shore transects at regular alongshore intervals. Once a profile is collected, follow-up surveys can be conducted using Emery rods. Emery rods use a basic rod-and-transit system that has been employed in community-based methods for monitoring coastal dynamics.

A toolkit can be provided to a local observing group and observations made at a much greater frequency than DEMs or GPS data can be collected.

\section{T-Sheets}

Coastal topographic map sheets compiled from maps derived in the field with a plane table, in the office from aerial photos, or using a combination of the two methods.

Historical shoreline surveys conducted by NOAA produced t-sheets, making them some of the oldest map datasets that show the elevation-derived position of the shoreline. T-sheets can be digitized, georeferenced, and used to delineate past shorelines, however, many of the t-sheets available for Alaska have not been processed in this way.

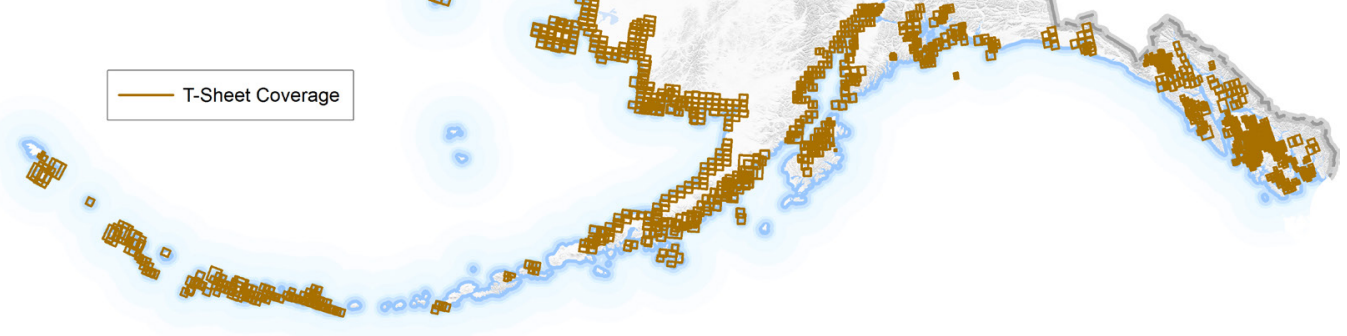

Communities where coastal elevation data have or are currently being collected shown in green. Data are made publicly accessible on the Alaska Coastal Profile Tool http://maps.dggs.alaska.gov/acpt/.
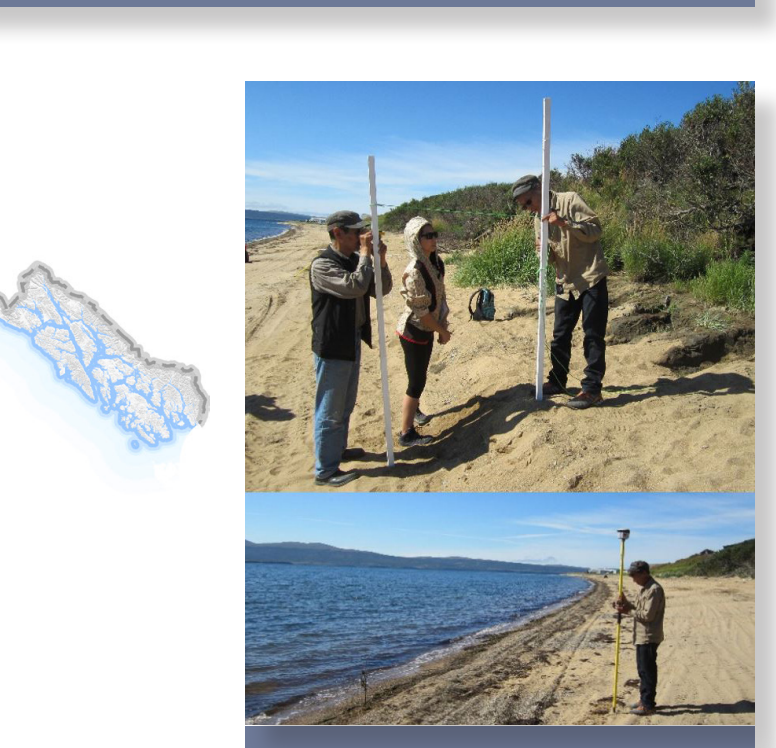

Jack Fagerstrom, Toby Anungazuk Jr. (Chinik Eskimo Community), and Denise Pollock (Alaska Institute for Justice) collecting Emery rod (top) and GPS (bottom) profiles at Golovin.

Coverage of T-Sheets in Alaska, not all T-sheets have been georeferenced. 


\section{Coastal Data}

\section{Shoreline Change}

Shoreline - the line along which a tidally

influenced body of water meets the land.

\section{Shorelines can be delineated from}

orthoimagery, elevation data, or

georeferenced t-sheets. By comparing

shorelines representing different times,

rates of shoreline change can be calculated

to document alongshore vulnerability to

erosion based on past trends. Shoreline data

available for Alaska are viewable in the

Alaska Shoreline Change Tool.

\section{Maximum Rate of \\ Documented Erosion (feet per year) \\ $\odot \quad-63.12$ \\ ○ -63.11 to -22.18 \\ $\odot-22.17$ to -7.32 \\ ○ $\quad-7.31$ to -4.27 \\ $\odot-4.26$ to -2.92 \\ ○ -2.91 to -1.77 \\ $\odot-1.76$ to -1.05 \\ $\odot-1.04$ to -0.46}

- Community experiencing erosion but with no measurements

Communities experiencing the most erosion are labeled with their name followed by the amount of documented total erosion.

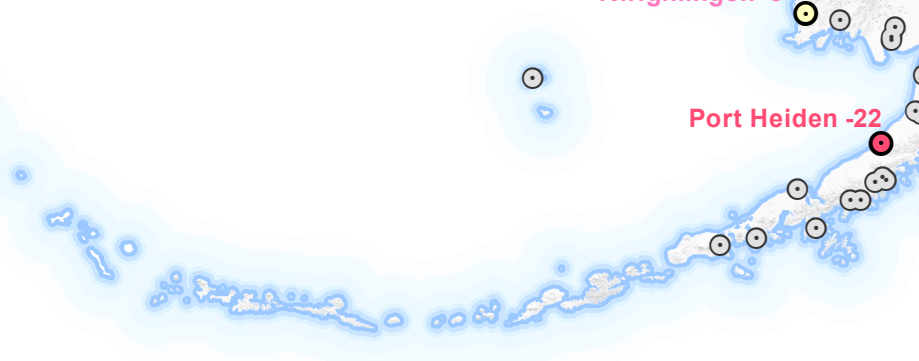

Maximum rate of historical erosion (feet per year) at or near community locations. Data were created by DGGS, USGS, and NPS using orthoimagery or topography through time. Communities that were listed by the U.S. Army Corps of Engineers as having erosion issues, but where no data exist are shown as gray circles (USACE, 2009). 


\section{Comparing Geospatial Datasets}

Coastal elevation and orthoimagery are the geospatial datasets that form the primary baselines for assessing flood and erosion hazards. Coastal geospatial datasets collected by state and federal agencies in the contiguous U.S. (CONUS) and Hawaii are compared datasets available in Alaska (table 1), along with idealized data quality and refresh rate for continued assessment of coastal flooding and erosion.

\begin{tabular}{|c|c|c|c|c|c|c|c|}
\hline $\begin{array}{c}\text { Collection Entity/ } \\
\text { Type }\end{array}$ & $\begin{array}{c}\text { Geospatial Data } \\
\text { Type }\end{array}$ & $\begin{array}{l}\text { Geospatial } \\
\text { Coverage }\end{array}$ & $\begin{array}{c}\text { Ground Sample } \\
\text { Distance (Pixel } \\
\text { Size) }\end{array}$ & $\begin{array}{l}\text { Horizontal } \\
\text { Accuracy }\end{array}$ & Vertical Accuracy & Refresh frequency & $\begin{array}{c}\text { Coastal Hazard } \\
\text { Use }\end{array}$ \\
\hline \multicolumn{8}{|c|}{ National Geospatial Datasets-Not Including Alaska } \\
\hline $\begin{array}{l}\text { NOAA NGS Remote } \\
\text { Sensing Division Pre- } \\
\text { storm Imagery } \\
\text { (King Air, Oblique) } \\
\text { (NOAA, 2016) }\end{array}$ & Orthoimagery & CONUS & $15-35 \mathrm{~cm}$ & $\begin{array}{l}\text { 5-10 m; not assessed } \\
\text { using check points }\end{array}$ & - & - & Emergency Response \\
\hline $\begin{array}{l}\text { NOAA NGS Remote } \\
\text { Sensing Division Post- } \\
\text { storm Imagery }\end{array}$ & Orthoimagery & CONUS & $\begin{array}{c}35-50 \mathrm{~cm} \text { (for datasets } \\
\text { collected between } 2011 \\
\text { and 2017) }\end{array}$ & Not assessed & - & On-storm basis & Emergency Response \\
\hline $\begin{array}{c}\text { NOAA T-Sheets } \\
\text { (georeferenced } \\
\text { topographic map sheets } \\
\text { dating back to the } 1800 \mathrm{~s} \text { ) }\end{array}$ & $\begin{array}{l}\text { Ground Mapping } \\
\text { Elevations }\end{array}$ & CONUS + Hawaii & - & Varies & $\begin{array}{c}\text { Varies; approximately } \\
\leq 1.5 \mathrm{~m}\end{array}$ & $10-20$ years & $\begin{array}{l}\text { Shoreline Change } \\
\text { Studies }\end{array}$ \\
\hline FEMA & Lidar Elevations & CONUS + Hawaii & $\mathrm{QL} 2 \leq 2 \mathrm{~m}$ & - & $\begin{array}{c}18.66 \mathrm{~cm} \text { for flat terrain } \\
37.32 \mathrm{~cm} \text { rolling hilly } \\
\text { terrain }\end{array}$ & - & Flood Studies \\
\hline $\begin{array}{c}\text { US Army Corps of } \\
\text { Engineers JALBTCX and } \\
\text { US Oceanographic Office } \\
\text { CHARTS }\end{array}$ & Lidar Elevations & CONUS & $\mathrm{QL} 2 \leq 2 \mathrm{~m}$ & - & $\leq 9.25 \mathrm{~cm}$ RMSEz & 5 years & $\begin{array}{c}\text { Shoreline Change } \\
\text { Studies; Flood Studies }\end{array}$ \\
\hline
\end{tabular}




\section{Coastal Data}

\begin{tabular}{|c|c|c|c|c|c|c|c|}
\hline $\begin{array}{c}\text { Collection Entity/ } \\
\text { Type }\end{array}$ & $\begin{array}{c}\text { Geospatial Data } \\
\text { Type }\end{array}$ & $\begin{array}{l}\text { Geospatial } \\
\text { Coverage }\end{array}$ & $\begin{array}{c}\text { Ground Sample } \\
\text { Distance (Pixel } \\
\text { Size) }\end{array}$ & $\begin{array}{l}\text { Horizontal } \\
\text { Accuracy }\end{array}$ & Vertical Accuracy & Refresh frequency & $\begin{array}{c}\text { Coastal Hazard } \\
\text { Use }\end{array}$ \\
\hline \multicolumn{8}{|c|}{ Geospatial Datasets Available in Alaska } \\
\hline $\begin{array}{l}\text { Historical Aerial Imagery } \\
\text { (circa 1950s-1980s) }\end{array}$ & Orthoimagery & $\begin{array}{c}\text { Northern and Western } \\
\text { Coast Alaska }\end{array}$ & $1-2 \mathrm{~m}$ & $\begin{array}{c}\text { 1.6-12.2 m (90\% } \\
\text { confidence; USGS, } \\
1947)\end{array}$ & - & - & $\begin{array}{c}\text { Shoreline Change } \\
\text { Studies }\end{array}$ \\
\hline $\begin{array}{l}\text { Statewide Digital } \\
\text { Mapping Initiative }\end{array}$ & Orthoimagery & Statewide & $2.5 \mathrm{~m}$ & $\begin{array}{c}12.2 \text { m (90\% confidence; } \\
\text { USGS, 1947) }\end{array}$ & - & $3-5$ years & - \\
\hline $\begin{array}{l}\text { Recent Aerial Imagery } \\
\text { (DGGS and USGS) }\end{array}$ & $\begin{array}{l}\text { Orthoimagery and } \\
\text { Surface Elevations }\end{array}$ & Western Coast Alaska & $\mathrm{QL} 4 \leq 40 \mathrm{~cm}$ & $\begin{array}{c}\leq 0.5 \mathrm{~m}(95 \% \\
\text { confidence; ASPRS, } \\
2014)\end{array}$ & 46.3-139 cm RMSEz & - & $\begin{array}{c}\text { Shoreline Change } \\
\text { Studies; Flood Studies }\end{array}$ \\
\hline $\begin{array}{l}\text { National Mapping } \\
\text { Initiative for Alaska }\end{array}$ & Ifsar Elevations & Statewide & $\mathrm{QL5} \leq 5 \mathrm{~m}$ & - & $\begin{array}{l}\text { 92.7-185 cm RMSEz } \\
\text { (+/- } 1.67 \text {-meters) }\end{array}$ & - & - \\
\hline 3DEP Lidar (USGS) & Lidar Elevations & $\begin{array}{c}\text { Mid-Yukon-Kuskokwim } \\
\text { Delta Alaska }\end{array}$ & $\mathrm{QL} 2 \leq 2 \mathrm{~m}$ & - & $\leq 9.25 \mathrm{~cm}$ RMSEz & - & $\begin{array}{c}\text { Shoreline Change } \\
\text { Studies; Flood Studies }\end{array}$ \\
\hline ArcticDEM & Surface Elevations & Statewide & $2 \mathrm{~m}$ and $5 \mathrm{~m}$ & Varies & Varies & Multi-year, not set & - \\
\hline \multicolumn{8}{|c|}{ Ideal Geospatial Datasets for Alaska for the Assessment of Coastal Flooding and Erosion } \\
\hline- & $\begin{array}{l}\text { Orthoimagery and } \\
\text { Surface Elevations }\end{array}$ & Statewide & $35-50 \mathrm{~cm}$ & $\begin{array}{c}\leq 0.734 \mathrm{~m} \\
\text { (95\% confidence; } \\
\text { ASPRS, 2014) }\end{array}$ & 46.3-139 cm RMSEz & 10 years & $\begin{array}{l}\text { Shoreline Change } \\
\text { Studies }\end{array}$ \\
\hline- & Orthoimagery & Statewide & $35-50 \mathrm{~cm}$ & $\begin{array}{c}\leq 0.5 \mathrm{~m} \\
\text { (95\% confidence; } \\
\text { ASPRS, 2014) }\end{array}$ & - & On-storm basis & Emergency Response \\
\hline- & Lidar Elevations & Statewide & QL1-QL2-2 m & - & $\leq 9.25 \mathrm{~cm}$ RMSEz & 10 years & $\begin{array}{c}\text { Shoreline Change } \\
\text { Studies; Flood Studies }\end{array}$ \\
\hline
\end{tabular}




\section{Bathymetry}

The measurement of water depth in

oceans, seas, or other large bodies of water.

Nearshore bathymetric data in Alaska is critical for the accuracy of coastal models used to forecast flooding and erosion. Available data are currently limited, with most being collected by NOAA's Office of Coast Survey (Coast Survey) to chart features for safe navigation of maritime commerce.

For northern and western Alaska, much of the data are either historic (1890s-1930s) or were collected as part of defense efforts during World War II (1930s-1950s). Bathymetric data collected by the Coast Survey only extend up to the 4-meter (13-foot) depth contour, which leaves a significant data gap in the surf zone.

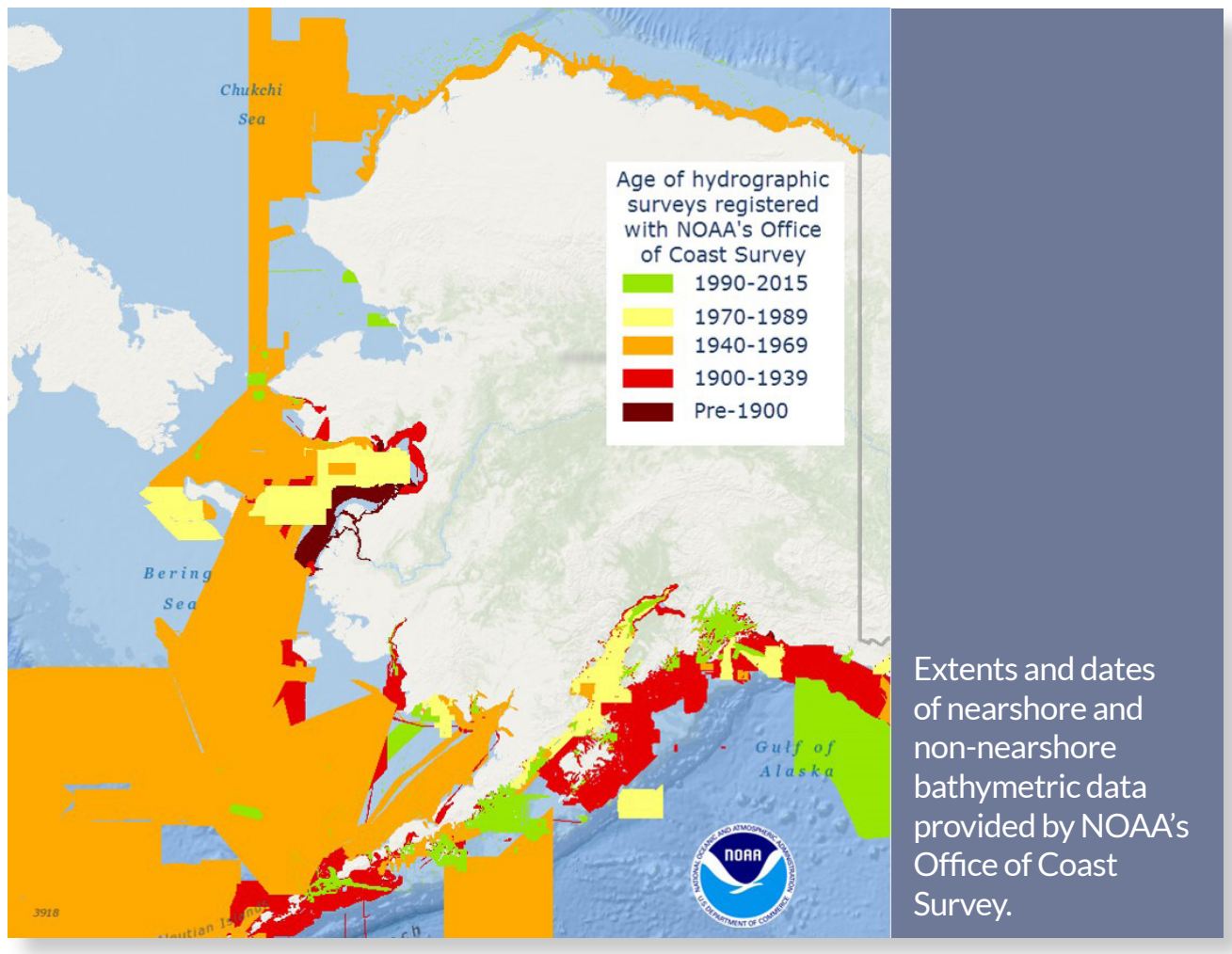

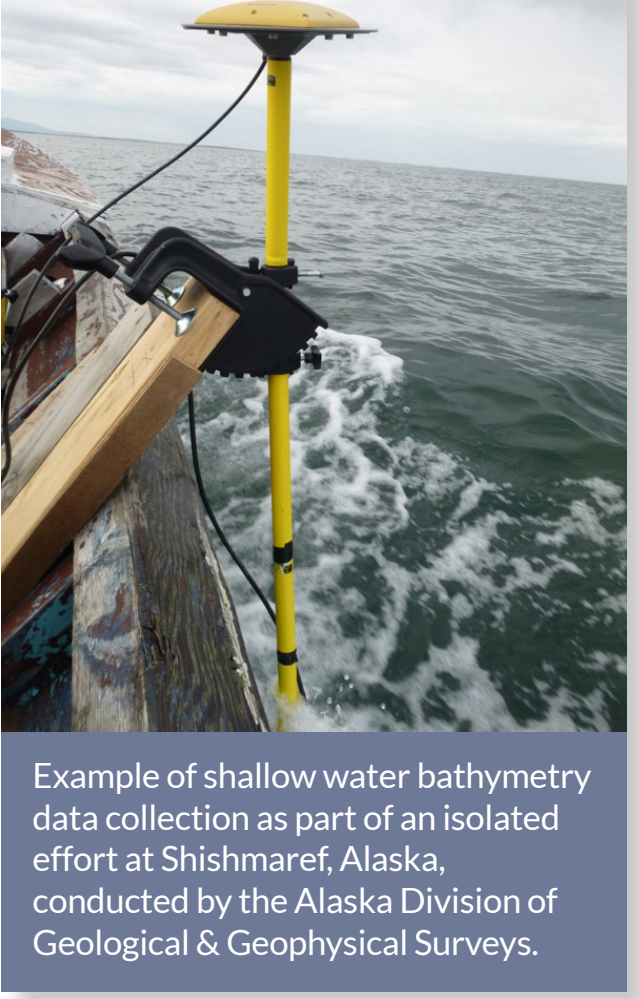

Due to the risks of collecting data in this shallow zone, there have been no large-scale efforts to map bathymetry above this depth contour. Only a few isolated projects in Alaska have generated this type of data. The lack of data in this critical zone greatly reduces the effectiveness of nearshore coastal models of flooding and erosion, particularly in northern and western Alaska, where the limiting depth contour can be far from the coastline and coastal storms regularly impact communities.

Advances in technology (e.g., topo-bathy lidar and satellite-derived bathymetry) are providing new opportunities to collect bathymetry in shallow water, but have yet to be significantly implemented in Alaska. 


\section{Coastal Data}

\section{Water Levels}

The elevation of the free surface of

a water body relative to a specified vertical datum.

The National Water Level Observation Network (NWLON) is the backbone of high-quality water level data in the U.S., there are, however, large gaps in NWLON coverage along Alaska's coast. The Alaska Ocean Observing System (AOOS) funds many projects to improve the quantity and quality of water level data, which are used for safe transportation in the nearshore zone, establishing tidal datums to standardize vertical reference systems, quantifying long-term relative sea level trends, and correcting bathymetric and shoreline surveys.

Water level data also contribute to improved storm surge and tidal models for accurate storm prediction, and flood event mapping.

National Water Level Observing Network Gaps (manually edited to reflect installation of Unalakleet gauge and

destruction of Port Moller gauge).

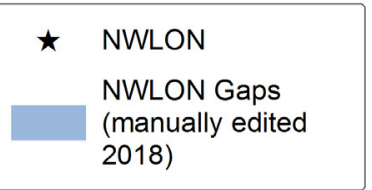

.

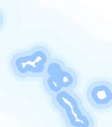

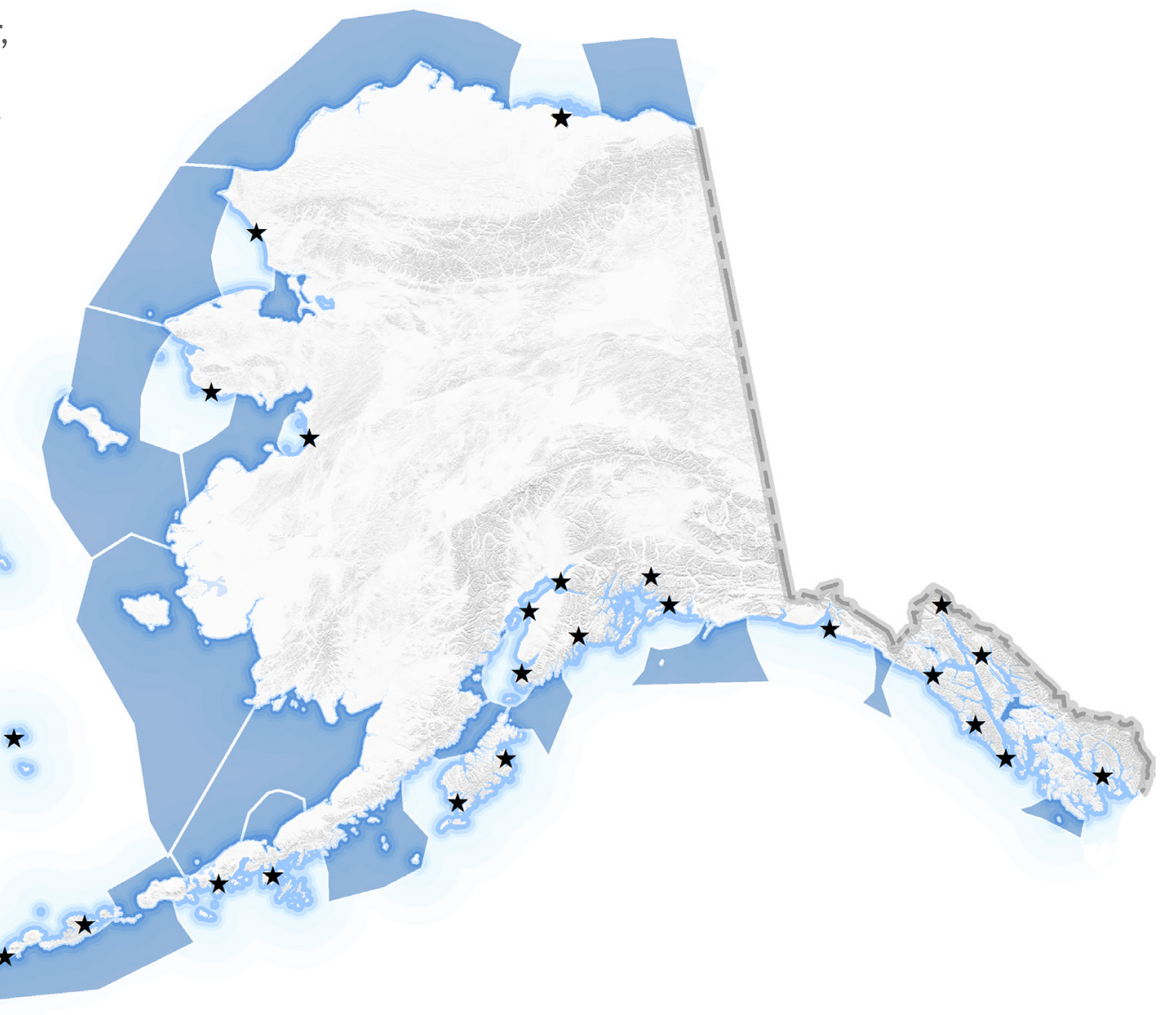




\section{Coastal Data}

\section{Alaska Water Level Watch}

The Alaska Water Level Watch (AWLW) is a collaborative group working to improve the quality, coverage, and accessibility to water level observations in Alaska's coastal zone. More information can be found here: https://www.aoos.org/alaska-water-level-watch/

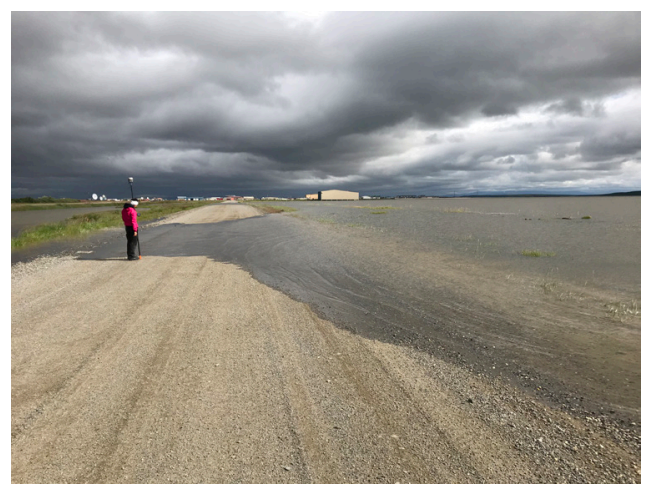

Flooding at Kotzebue, July 2018

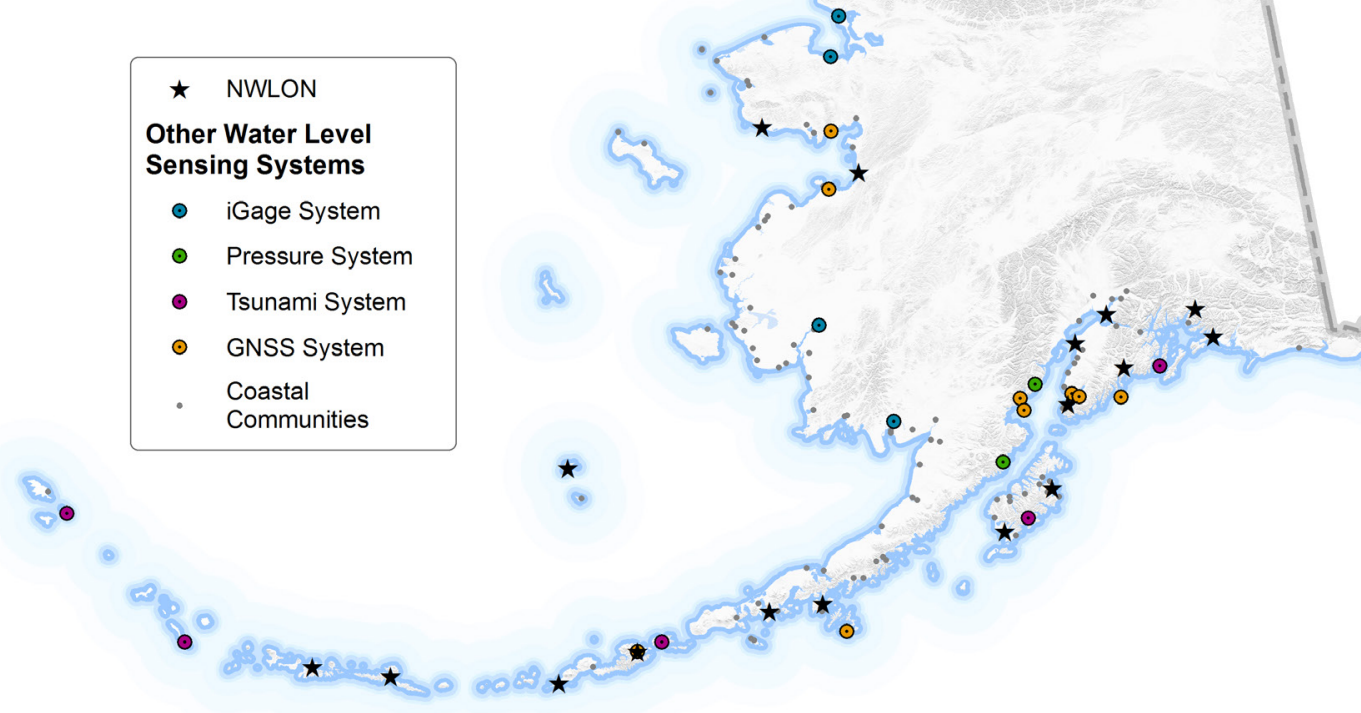

Improvements in water level sensing technology and availability in real-time
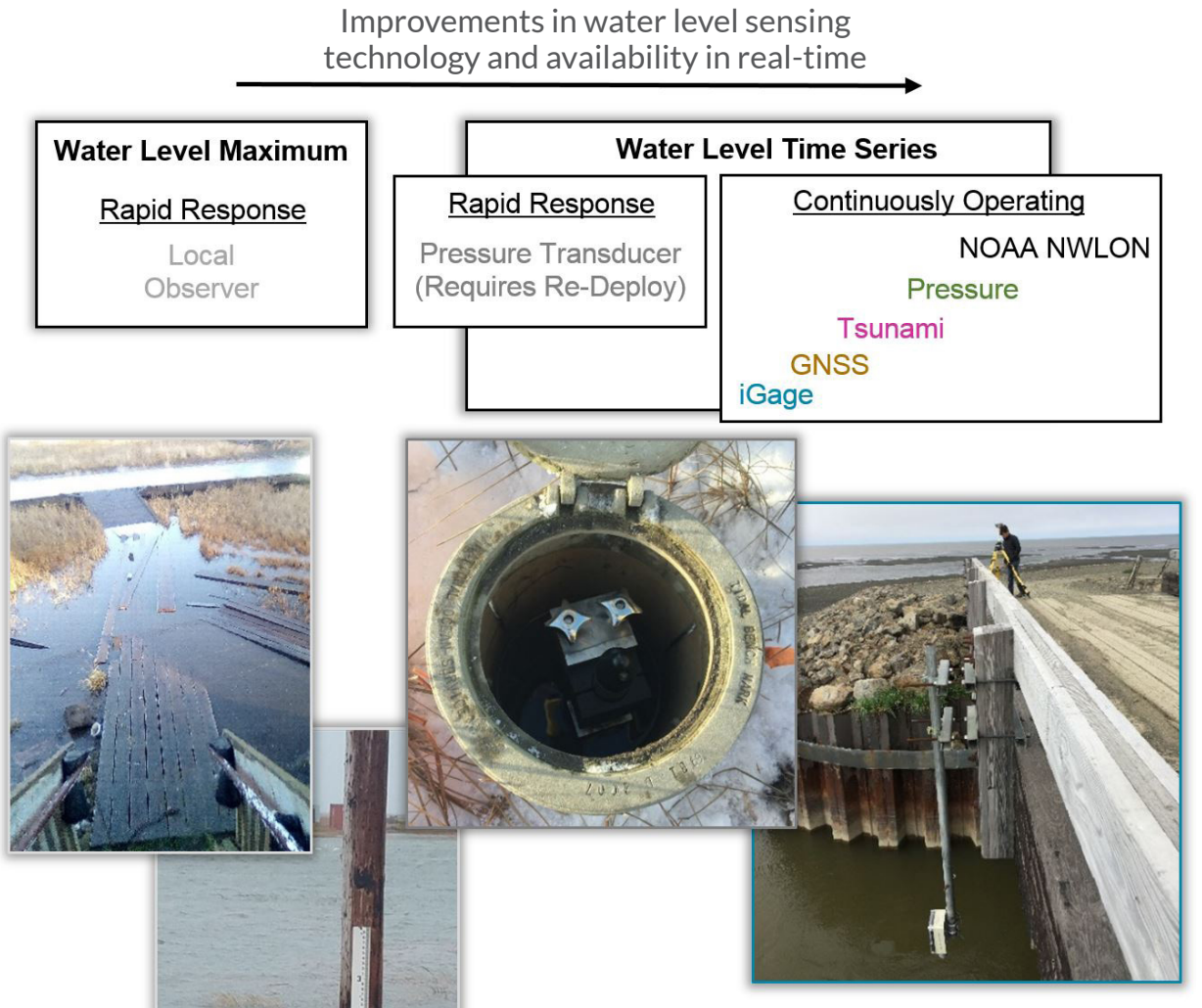

Above. Right. Schematic showing the types of sensors associated with improvements in technology and real-time capabilities.

Left. Water levels sensors that use alternate technologies to the NOAANWLON. Sensors installed and operated by collaborative partners, including: National Tsunami Warning Center, National Park Service, State of Alaska, Alaska Ocean Observing Systems, research groups, and others. 


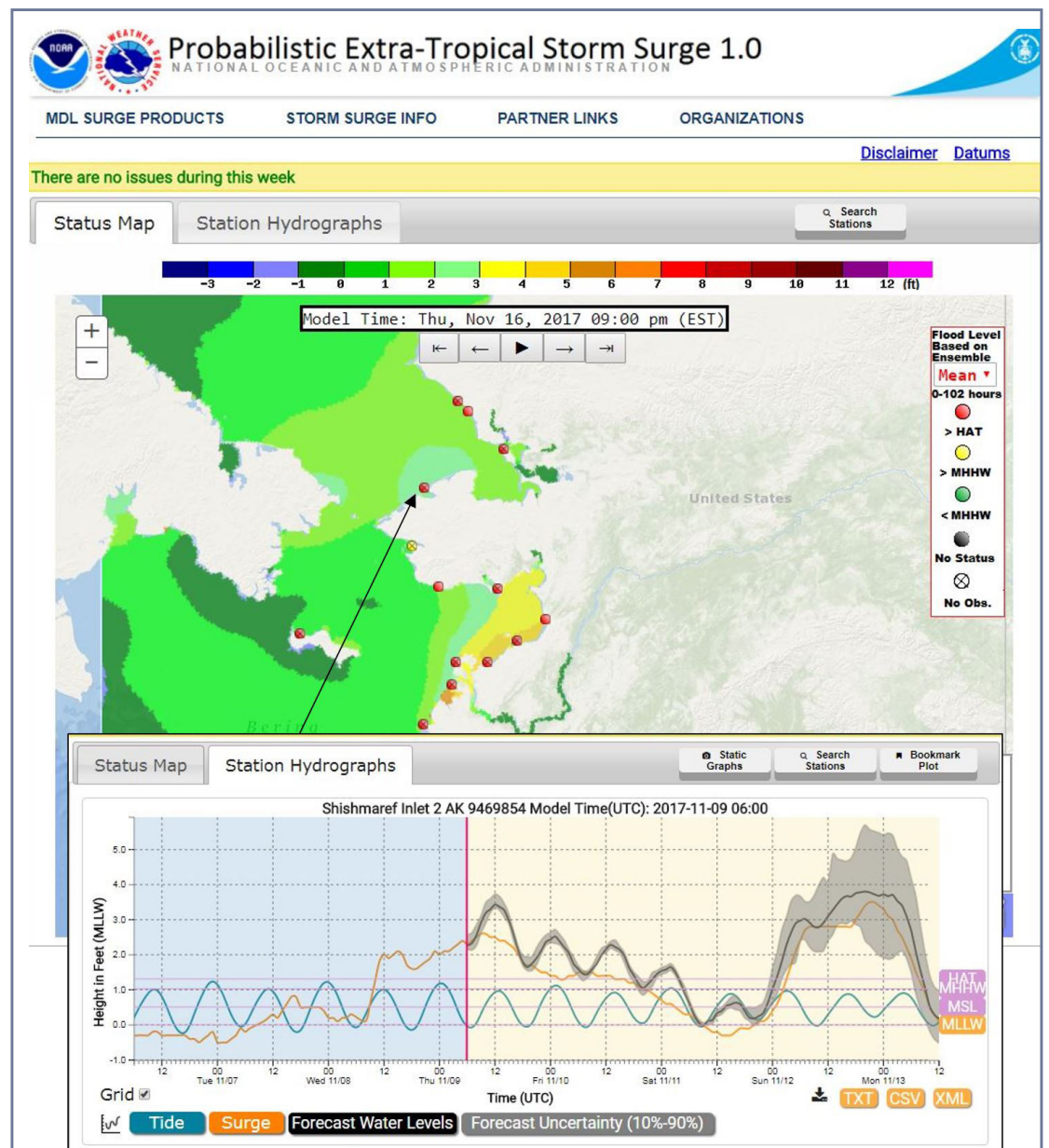

Above. National Center for Environmental Prediction probabilistic extratropical storm surge model website graphic, http://slosh.nws. noaa.gov/etss/station/petss1.0esri/ (NOAA, 2017e).

Right. Schematic of Marine Total Water Level, showing each component that adds up to inundation of the coast.

\section{Water Level Models}

\section{Marine Total Water Level}

\section{Sum of water level components that}

results in an elevation of water level at the shore.

Operational water level models compute components of the Marine Total Water Level (MTWL). NOAA's National Centers for Environmental Prediction (NOAA-NCEP) models the tide and storm surge components of MTWL, however, the locations of stations do not cover all Alaska communities. Model predictions are also not validated for most stations. Wave-induced water levels are not included in the NOAA-NCEP model, nor do any other models run for Alaska.

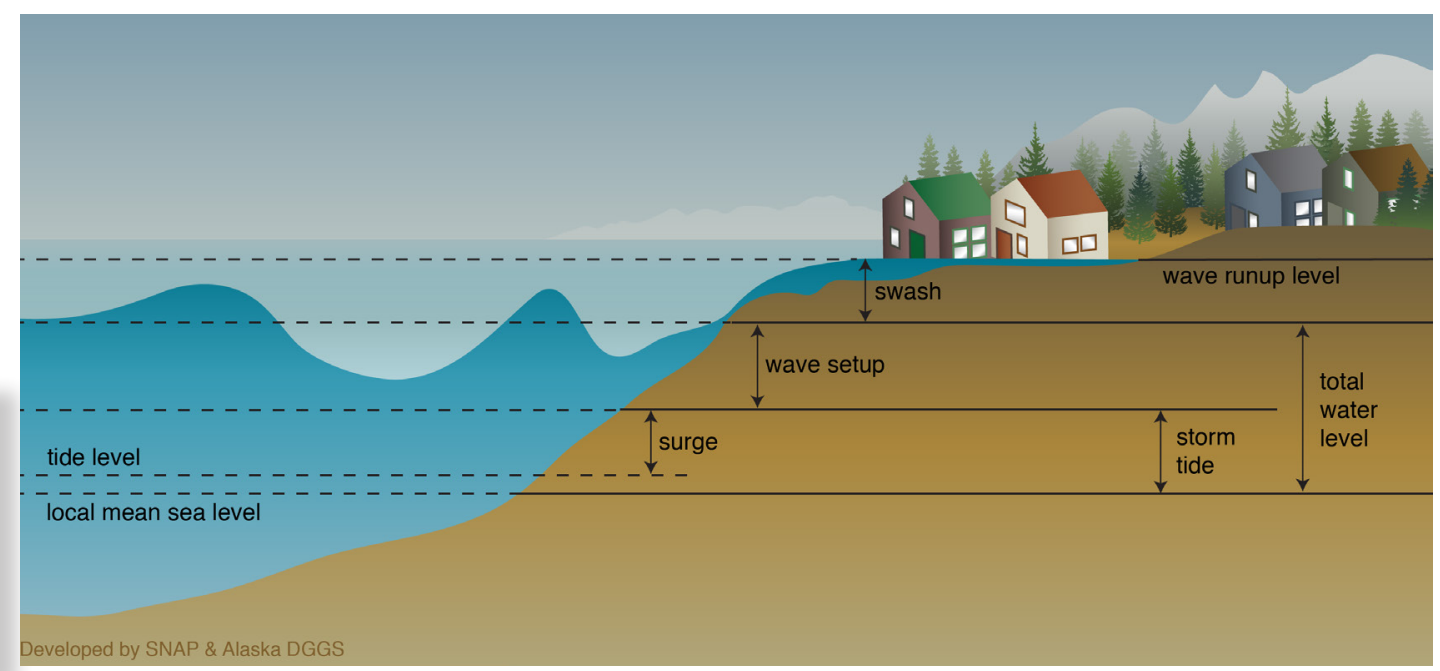




\section{Coastal Data}

\section{Tidal Datums}

Datum - A reference point from which to measure position, including heights or depths.

Tidal Datum - a standard elevation defined by a certain phase of the tide, used as a reference to measure local water levels.

Tidal datums are calculated from local water level data. They are used in flood prediction to model storm water levels. When linked to land-based datums, they provide a necessary conversion for storm forecasting and floodplain mapping. Water level data and tidal datums have not been collected or linked to land-based datums for most communities in western Alaska.

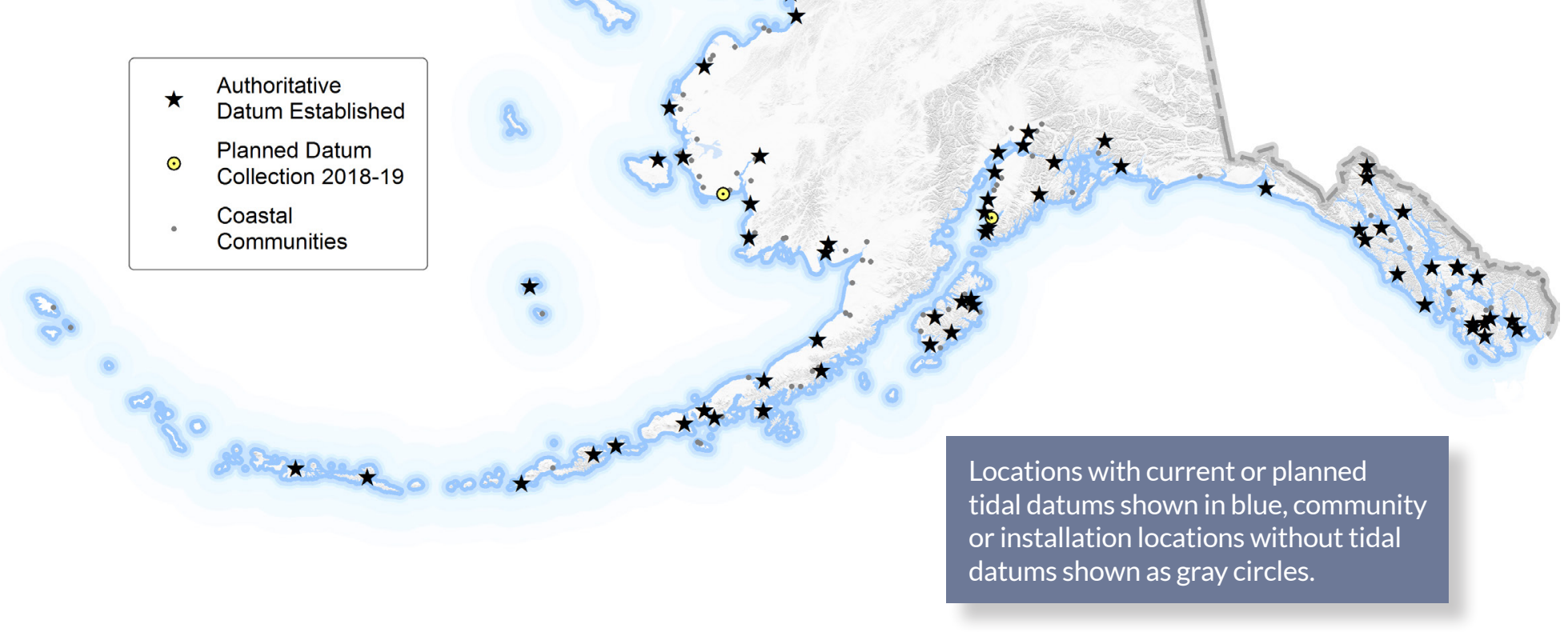




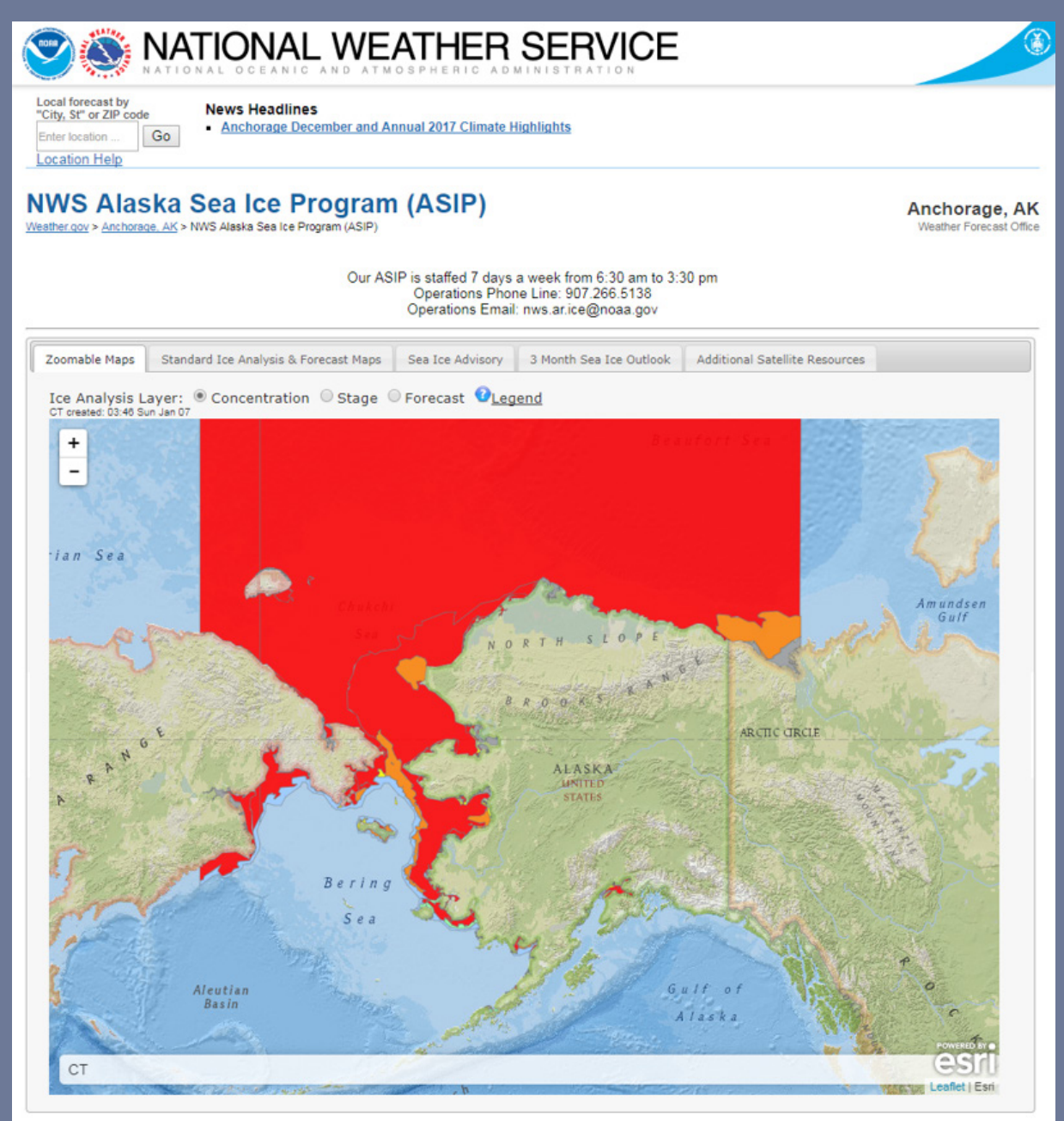

National Weather Service Alaska Sea Ice Program website graphic, https://www.weather.gov/afc/ice (NOAA, 2017a).

\section{Sea Ice}

Sea ice can help mitigate flood and erosion

hazards by providing protection against incoming waves and dampening wave and surge development offshore. The ice-free ocean season is expected to continue expanding throughout the $21^{\text {st }}$ century (Douglas, 2010). Ice-free conditions during the regular fall and winter storm season allow waves and surge to develop and damage land and infrastructure in Alaska coastal communities.

\section{Sea Ice Analysis}

The National Weather Service maintains a daily sea ice analysis mapping service that provides near real-time updates of sea ice conditions. The National Snow and Ice Data Center has been cataloging sea ice extent since 1971. These are critical datasets used to model Alaska storm surge. Most satellite data can be hampered by cloud cover, and there are few local ice condition observations available to ground truth forecasts.

Sea ice analysis data sources.
Primary Data Sources
Synthetic Aperture Radar (SAR) from
National Ice Center (NIC)
SAR wind data from the NOAA National
Environmental Satellite, Data, and Infor-
mation Service
Satellite Data (Worldview, MODIS,
Suomi NPP, and NASA MODIS)
NIC marginal ice zone daily analysis

\section{Additional Data Souces}

\section{Operational vessel observations} (USCG, Healy, and others)

NWSWeather Station Office field observations Nearshore webcams and radar (Utqiagvik) Canadian Ice Service graphical ice analysis Seasonal field research and observations
Local resident observations and communications




\section{Coupled Sea Ice-Water Level Models}

There are many poorly understood processes important for modeling sea ice-water level interactions. The operational model for water levels, Probabilistic ExtraTropical Storm Surge (P-ETSS), does not accurately model these interactions. This leads to anomalous forecasts during times when sea ice is either fully or partially covering the offshore or nearshore regions of Alaska. More research and observations of sea ice-water level interactions are needed to effectively forecast flooding from coastal storms during Alaska's fall and winter storm season.

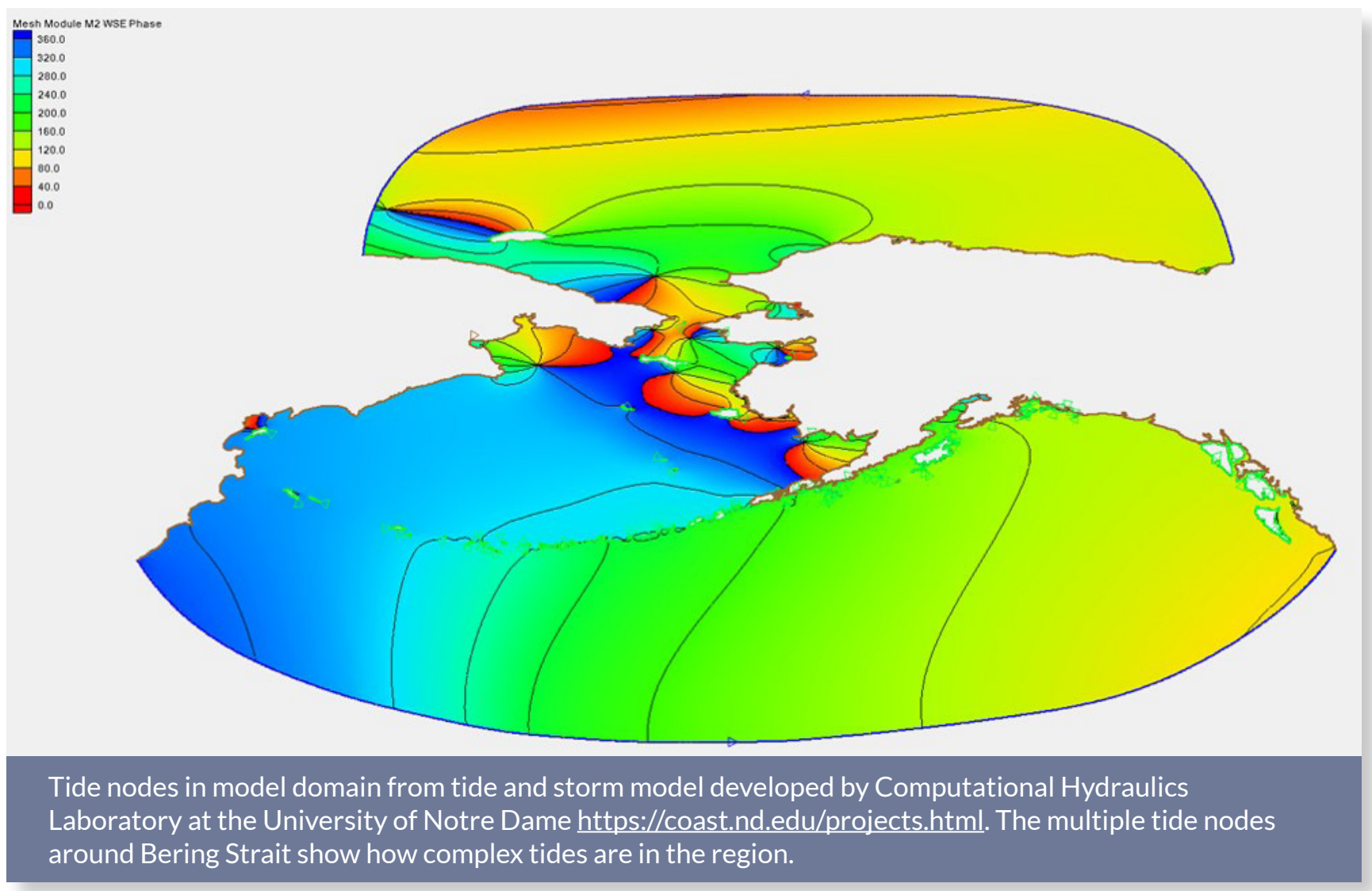




\section{Coastal Data}

\section{Waves}

Wave data are collected by real-time operational buoy systems, data are available through the National Buoy Data Center (NBDC). Wave data are used to construct wave climatologies (the distribution of wave characteristics averaged over a period of time and for a particular location) and model storm impact potential. Real-time wave data are also critical to marine traffic, which has historically been dominant in southern Alaska but is increasingly moving through Bering Strait and along the northern coast.

\section{Wave Models}

Wave data are used to inform wave models, which provide wave data over a much larger and continuous area.

The U.S. Army Corps of Engineer's Wave Information Studies (WIS) includes most of western Alaska. Available data include yearly wave height time series, wave climate, and extreme wave analysis. These data are available for approximately 20-50 $\mathrm{m}$ (66-164 ft) water depth, which does not allow the user to look at waves in the nearshore.

Nearshore wave models are necessary for real-time or hindcast modeling of flooding and erosion and are not readily available for most of the state.

Top. National Data Buoy Center operational and delayed (in need of repair) buoy stations. No stations are operated north of the Bering Sea, http:// www.ndbc.noaa.gov/ (NOAA, 2017d).

Right. Wave Information Studies (WIS) data sites. Numbers inside colored circles show the number of WIS sites available when zoomed into that region, http://wis.usace.army.mil/ (USACE, 2017).

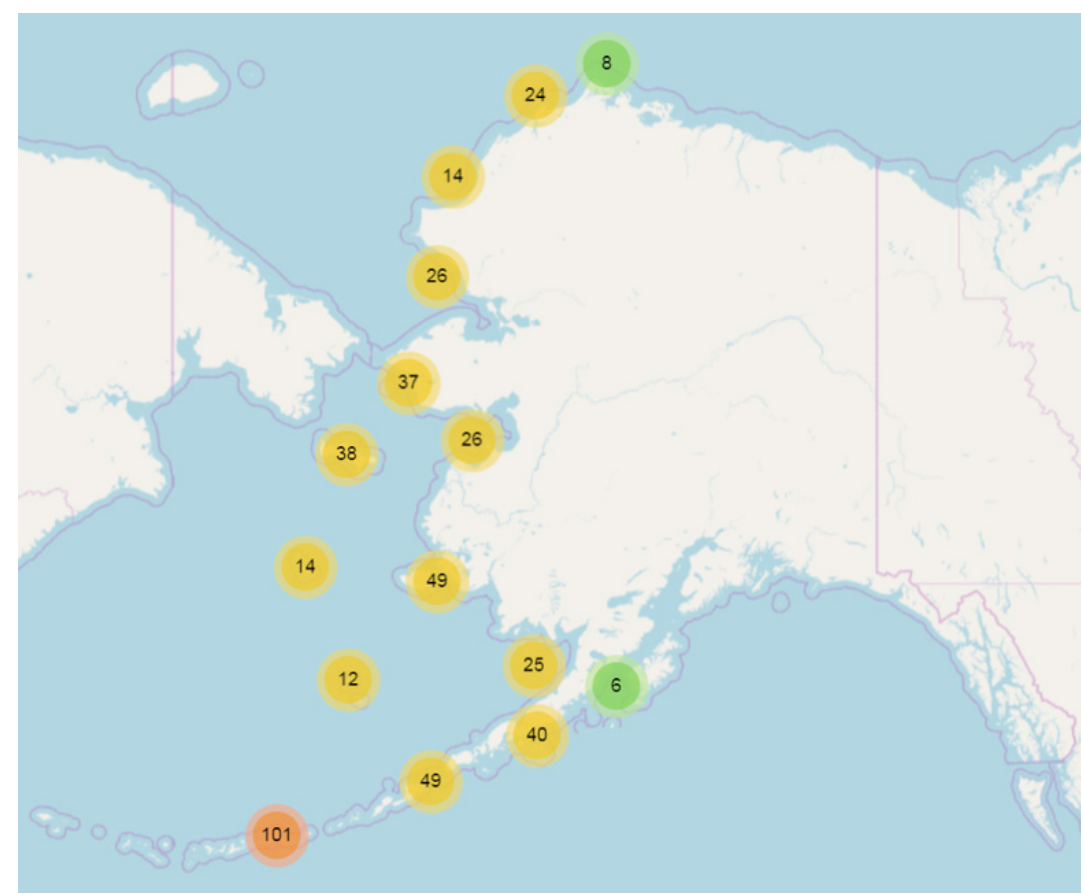




\section{Continuous GPS Sites}

Continuously Operating Reference Stations (CORS)

GPS stations that establish the

known $x, y$, and $z$ coordinates of a particular, fixed location.

CORS data are used to determine the rates of land rise or fall, which are compared to local sea level to calculate relative sea level change. CORS data are also used to correct kinematic GPS surveys (bathymetry/ topography). Data from the CORS have a recommended usable range of $\sim 100 \mathrm{~km}(\sim 62 \mathrm{mi})$, leaving large coverage gaps throughout northern and western Alaska.

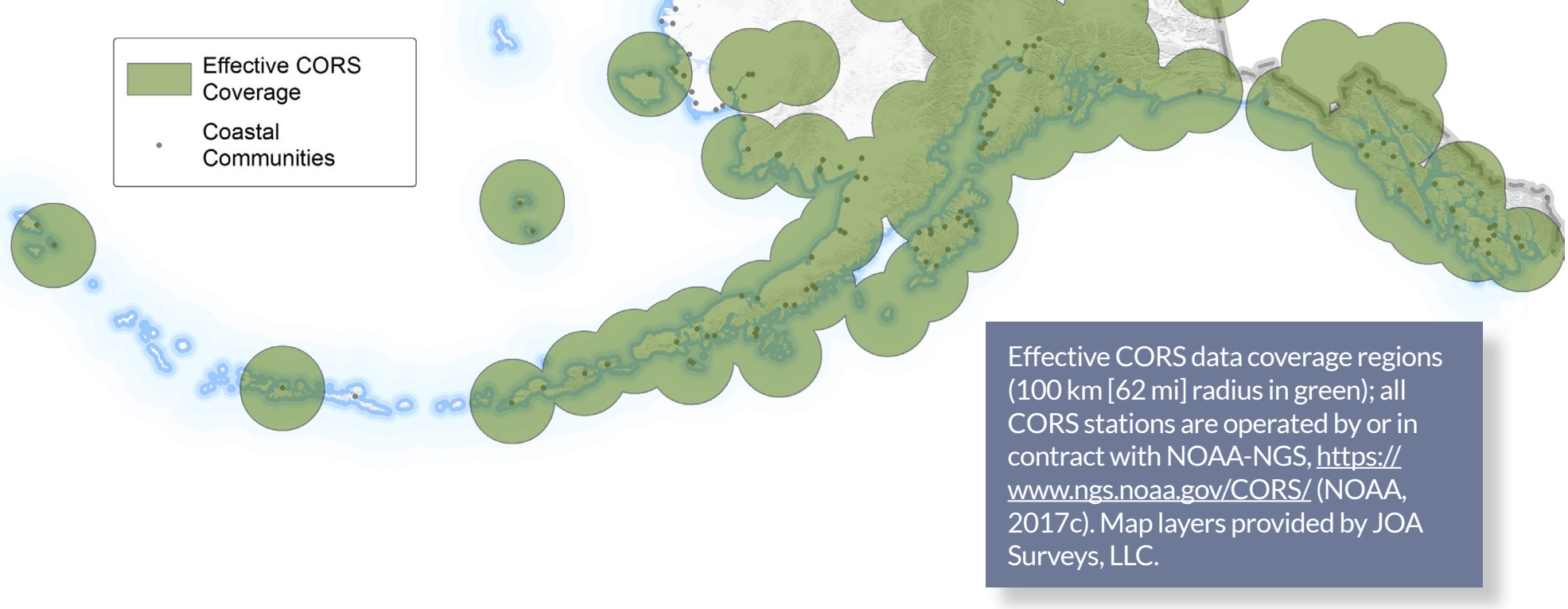




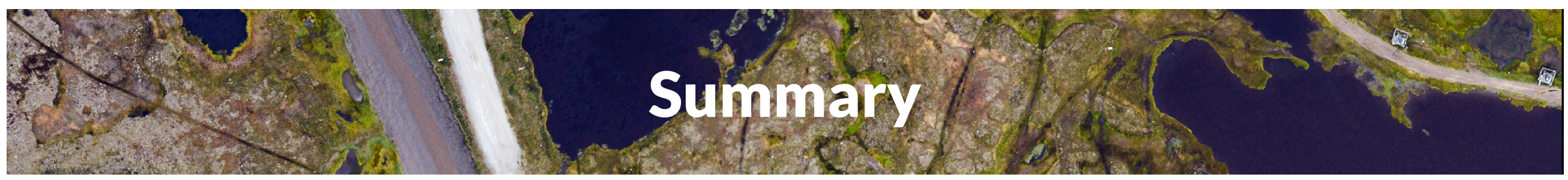

\section{Baseline Data Needs}

Orthorectify additional historical aerial datasets over northwest and north slope regions

New orthoimagery over northwest Alaska

Plan to refresh high resolution orthoimagery, optimally every 5 years over regions with high rates of shoreline change and 10 years over regions with lower rates of shoreline change

Delineate shorelines on all orthoimagery datasets for shoreline change studies and shoreline boundaries

Targeted high resolution elevation data and necessary ground control and check points over remaining communities (including lidar where communities have high density of vegetation)

Cross-shore elevation profiles for community-based monitoring

Nearshore bathymetric data from the swash zone to the 40-m (130-ft) depth contour approaching community locations

Geodetically reference water level station occupations at community locations to establish tidal datums

Continuously operating or ice-free seasonally operating water level stations

Additional community-based monitoring of water level maximums from storms

Storm surge water level model output at all Alaska communities

Predictive model of wave-induced water levels

Cloud cover-capable satellite data

Additional localized (vessel, field, and community-based) observations of sea ice

Sea lce

Research to understand sea ice-water level interactions and how to model them

Wave buoys in and north of Bering Sea

Nearshore wave models for northern and western Alaska

Waves

Onshore wave measurements at multiple communities representing different coastal settings

Fill gaps between CORS stations in northern and western Alaska

Orthoimagery

Topography

Bathymetry

Water Levels

CORS 


\section{Flood Mapping \& Forecasting}

Flood mapping and forecasting use layers of baseline data stacked together to interpret local flood vulnerability. Each data layer depends on the other layers to be accurate and usable for these purposes.

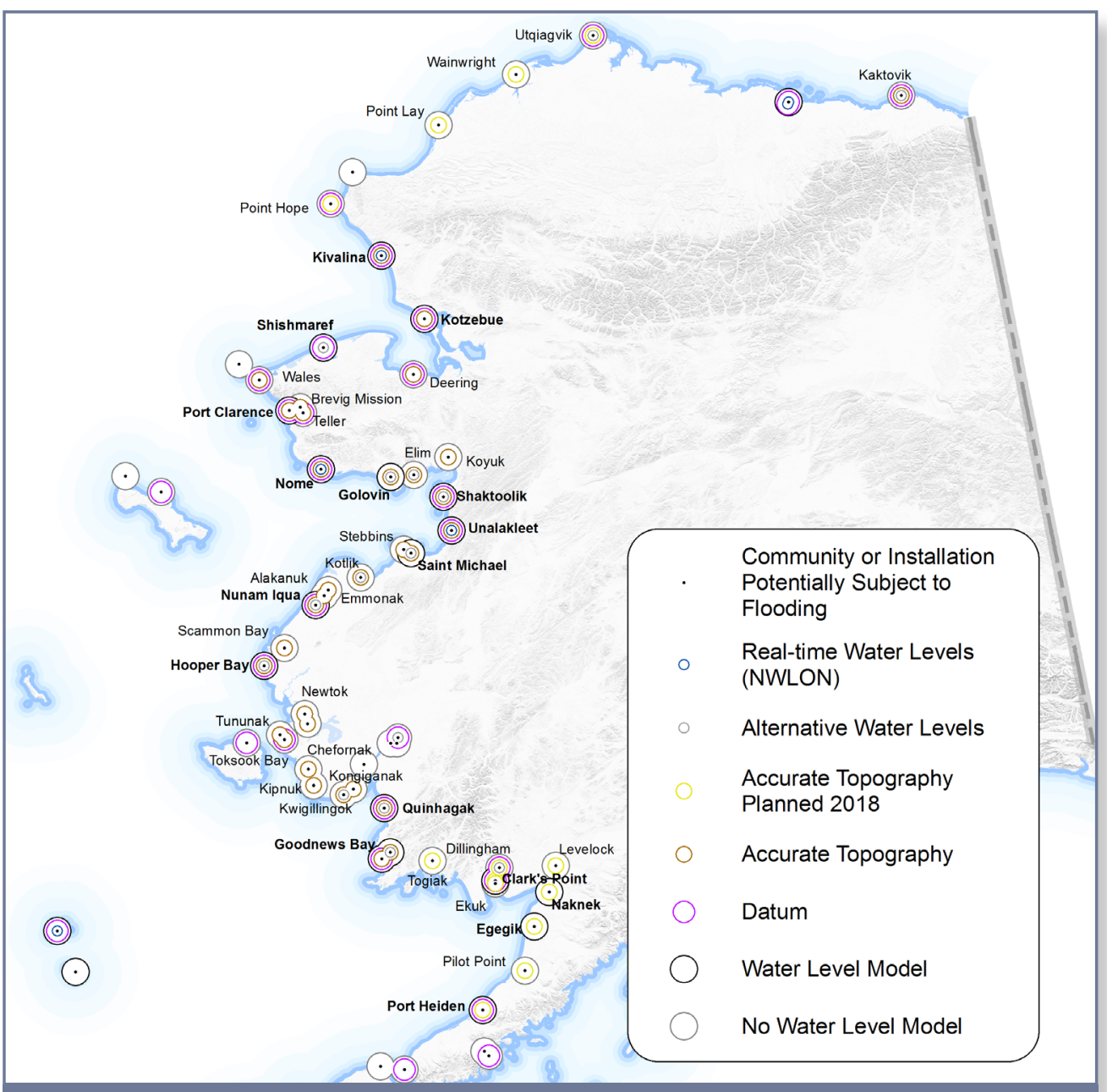

Baseline data layers currently available for flood mapping and forecasting in northern and western Alaska communities.
Percentage of communities with baseline foundational data and model data necessary for erosion mapping and forecasting. The total number of communities includes those located on the northern and western coastlines (total of 63).

\begin{tabular}{|c|c|c|}
\hline & Dataset & $\begin{array}{c}\text { Percentage of } \\
\text { Communities or } \\
\text { installations }\end{array}$ \\
\hline \multirow{3}{*}{ Model Data } & $\begin{array}{l}\text { Wave Runup } \\
\text { Model }\end{array}$ & $0 \%$ \\
\hline & $\begin{array}{c}\text { Nearshore Wave } \\
\text { Model }\end{array}$ & $0 \%$ \\
\hline & $\begin{array}{l}\text { Storm Surge } \\
\text { Model }\end{array}$ & $27 \%$ \\
\hline \multirow{6}{*}{$\begin{array}{c}\text { Baseline } \\
\text { Foundational } \\
\text { Data }\end{array}$} & $\begin{array}{c}\text { Sea Ice Interaction } \\
\text { Observation }\end{array}$ & $0 \%$ \\
\hline & Wave Observation & $0 \%$ \\
\hline & $\begin{array}{l}\text { Nearshore } \\
\text { Bathymetry }\end{array}$ & $10 \%$ \\
\hline & $\begin{array}{l}\text { Water Level } \\
\text { Observation }\end{array}$ & $10 \%$ \\
\hline & $\begin{array}{l}\text { Accurate } \\
\text { Topography }\end{array}$ & $71 \%$ \\
\hline & Tidal Datum & $44 \%$ \\
\hline
\end{tabular}




\section{Erosion Mapping \& Forecasting}

Similarly, erosion mapping and forecasting use layers of baseline data stacked together to interpret local vulnerabilities to erosion.

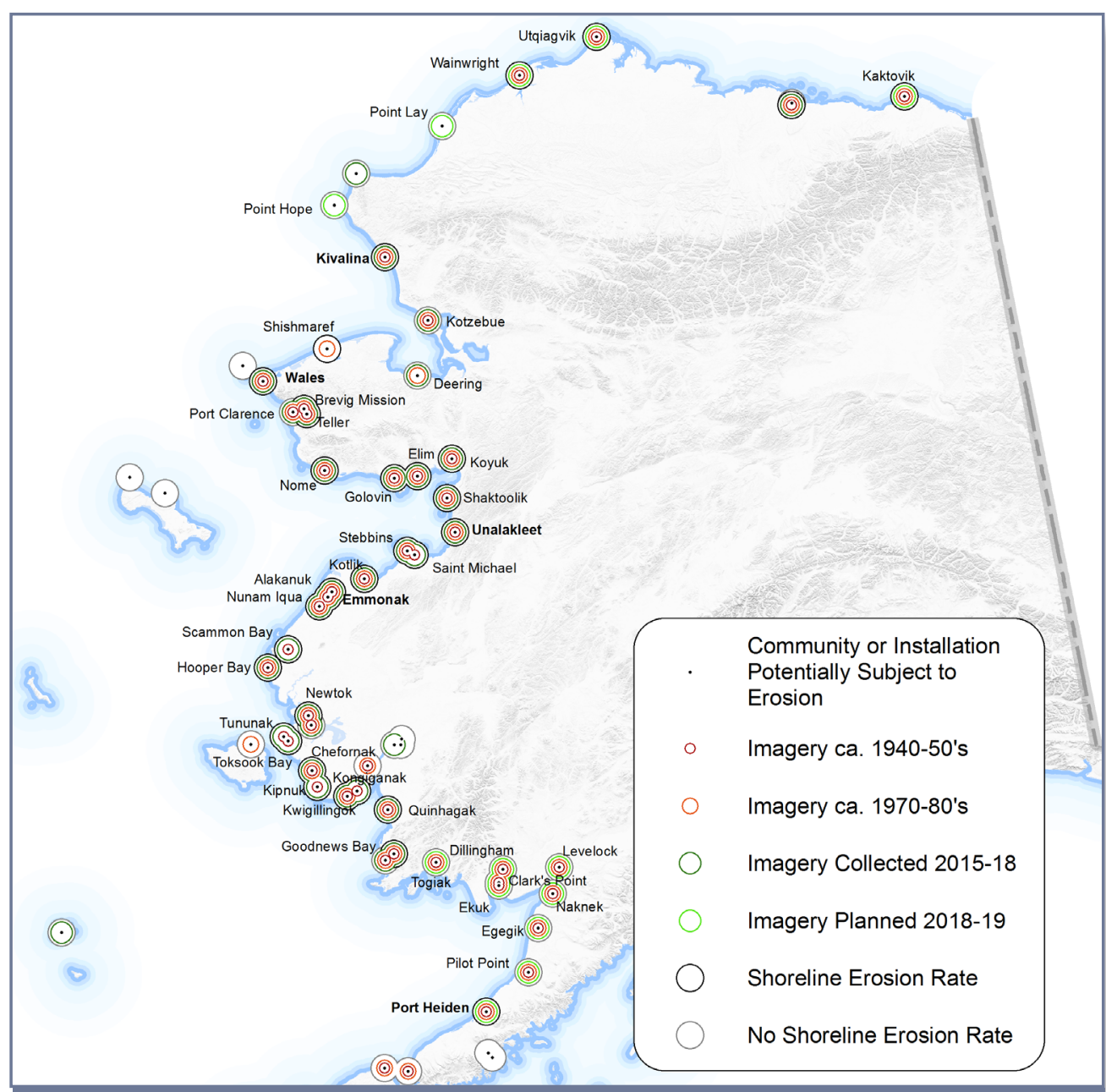

Baseline data layers currently available for shoreline change mapping and forecasting in northern and western Alaska communities.
Percentage of communities with baseline foundational data and model data necessary for erosion mapping and forecasting. The total number of communities includes those located on the northern and western coastlines (total of 63).

\begin{tabular}{|c|c|c|}
\hline & Dataset & $\begin{array}{l}\text { Percentage of } \\
\text { Communities or } \\
\text { installations }\end{array}$ \\
\hline \multirow{2}{*}{ Model Data } & $\begin{array}{c}\text { Projected } \\
\text { Shoreline Position }\end{array}$ & $8 \%$ \\
\hline & $\begin{array}{c}\text { Shorline Erosion } \\
\text { Rate }\end{array}$ & $54 \%$ \\
\hline \multirow{3}{*}{$\begin{array}{c}\text { Baseline } \\
\text { Foundational } \\
\text { Data }\end{array}$} & $\begin{array}{l}\text { Imagery ca. 1940- } \\
1950 \mathrm{~s}\end{array}$ & $75 \%$ \\
\hline & $\begin{array}{c}\text { Imagery ca. } 1970- \\
1980 \text { s }\end{array}$ & $70 \%$ \\
\hline & $\begin{array}{c}\text { Recently Collected } \\
\text { or Planned } \\
\text { Imagery }\end{array}$ & $79 \%$ \\
\hline
\end{tabular}




\section{Benefits for Alaskans}

Effective flood and erosion mapping

Continous and consistent flood and erosion forecasting

Accurate flood and erosion modeling and prediction
Informed state, regional, and community climate adaptation planning

Effective engineering in the coastal zone

Disaster preparation

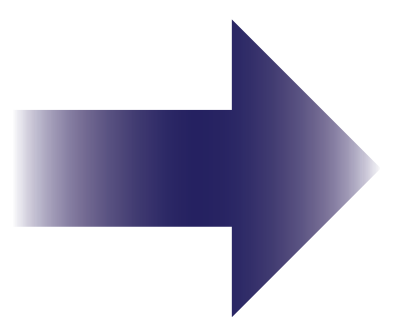

Stable, safe, and resilient communities and mitigation

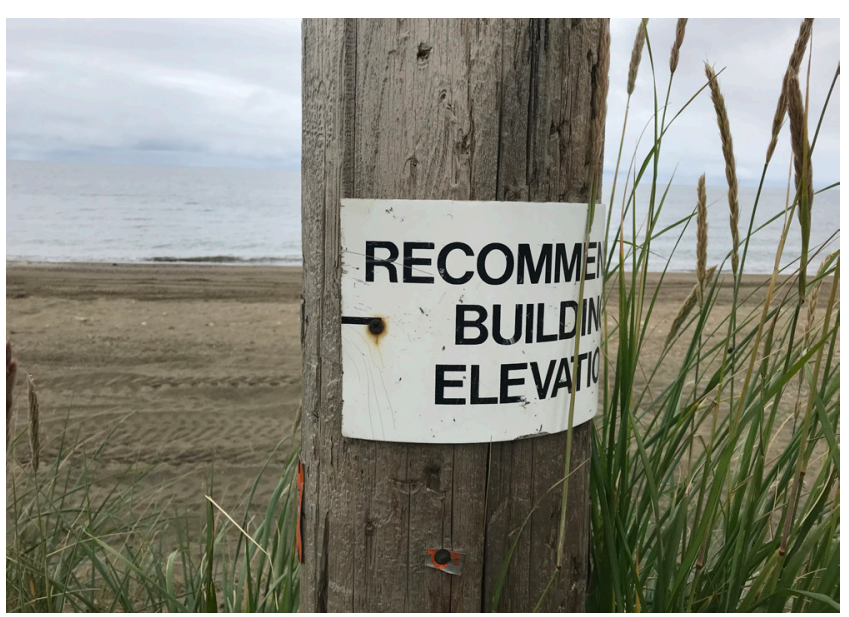

Recommended building elevation in Deering, surveyed July 2018

\section{Acknowledgments}

This document was written with contributions from public and private experts of Alaska coastal studies, sea ice, hydrographic survey, coastal community resilience, and geospatial data.

Contributors: Bart Buesseler (NOAA Office of Coast Survey), Ann Gibbs (U.S. Geological Survey), Michael Hendricks (Alaska Department of Natural Resources), Rebecca Heim (NOAA National Weather Service), Davin Holen (Alaska Sea Grant), Nicole Kinsman (NOAA National Geodetic Survey), Anne Johnson (Alaska Department of Natural Resources), MaryBeth Schreck (NOAA National Weather Service), Richard Thoman (NOAA National Weather Service), and Nathan Wardwell (JOA Surveys, LLC). 


\section{References}

Alaska Ocean Observing Systems (AOOS), 2016, Coastal and nearshore water level observations in Alaska: challenges, assets, gaps, and next steps, version 1.0. http://www.aoos.org/wp-content/ uploads/2011/05/2016_Alaska_Water_Level Observations $\vee 1-0 . p d f$

American Society for Photogrammetry and Remote Sensing (ASPRS), 2011, LAS specification version 1.4-R13: Bethesda, Md., American Society for Photogrammetry and Remote Sensing, 27 p. http:// www.asprs.org/Committee-General/LASer-LASFile-Format-Exchange-Activities.html

- - -2014, Positional accuracy standards for digital geospatial data-draft revision 5, version 1: American Society for Photogrammetry and Remote Sensing, 39 p. http://www.asprs.org/a/ society/divisions/pad/Accuracy/ASPRS Positional Accuracy_Standards_for_Digital_Geospatial_Data_ Draft Rev5 V1.pdf

DeGrandpre, K., 2015, Relative sea level change in western Alaska as constructed from repeat tide gauge and GPS measurements [thesis]: University of Alaska Fairbanks, Department of Geology \& Geophysics. https://scholarworks.alaska.edu/ handle/11122/6076

Douglas, D.C., 2010, Arctic sea ice decline: Projected changes in timing and extent of sea ice in the Bering and Chukchi seas: U.S. Geological Survey Open-File Report 2010-1176, 32 p. https://pubs.usgs.gov/ of/2010/1176/pdf/ofr20101176.pdf

Federal Geographic Data Committee (FGDC), 1998, Geospatial Positioning Accuracy Standards, Part 3-National Standard for Spatial Data Accuracy (FGDC-STD-007.3-1998). http://www.fgdc.gov/ standards/projects/FGDC-standards-projects/ accuracy/part3/index_html/? searchterm=FGDCSTD-007.3-1998

Gibbs, A.E., and Richmond, B.M., 2015, National assessment of shoreline Change-Historical shoreline change along the north coast of Alaska, U.S.-Canadian border to Icy Cape: U.S. Geological Survey Open-File Report 2015-1048, 96 p. https:// dx.doi.org/10.3133/ofr20151048
Immediate Action Working Group (IAWG), 2009, Recommendations Report to the Governor's Subcabinet on Climate Change: IAWG. https://dec. alaska.gov/climate-change/

Jorgenson, T., Yoshikawa, K., Kanevskiy, M., Shur, Y., Romanovsky, V., Marchenko, S., Grosse, G., Brown, J., and Jones, B., 2008, Permafrost characteristics of Alaska: Ninth International Conference on Permafrost, June 29-July 3, 2008, Fairbanks, Alaska. http://permafrost.gi.alaska.edu/sites/ default/files/AlaskaPermafrostMap Front Dec2008 Jorgenson etal 2008.pdf

Krauss, M., G. Holton, Kerr, J., and West, C.T. 2011. Indigenous Peoples and Languages of Alaska. Fairbanks and Anchorage: Alaska Native Language Center and UAA Institute of Social and Economic Research. http://www.uaf.edu/anla/map

National Aeronautics and Space Administration (NASA), June 2013, Rare clear view of Alaska [high res]: NASA Goddard Space Flight Center. https://www. flickr.com/photos/gsfc/9084013645/

National Oceanic and Atmospheric Administration (NOAA), 2014, A network gaps analysis for the national water level observation network: updated edition. https://tidesandcurrents.noaa. gov/publications/Technical Memorandum NOS COOPS 0048 Updt.pdf

- - -2016, NOAA oblique imagery metadata. https:// geodesy.noaa.gov/storm archive/storms/common/ coastal oblique metadata.htm

- - -2017a, Alaska Sea Ice Program. https://www. weather.gov/afc/ice

- - - 2017b, Bathymetric data viewer. https://maps. ngdc.noaa.gov/viewers/bathymetry/

- - -2017c, Continually operating reference stations. https://www.ngs.noaa.gov/CORS/

- - -2017d, National data buoy center. http://www. ndbc.noaa.gov/

- - - 2017e, Probabilistic extra-tropical storm surge 1.0. http://slosh.nws.noaa.gov/etss/station/ petss1.0esri/

- - - 2017f, Sea level trends. https://tidesandcurrents. noaa.gov/sltrends/s/trends.html
ShoreZone, 2017, Shorezone shore types. https://www. shorezone.org

Thoman, R., 2017, Record low sea ice in Alaska waters in fall 2017. https://www.climate.gov/news-features/ featured-images/record-low-sea-ice-alaska-watersfall-2017

U.S. Army Corps of Engineers (USACE), March 2009, Alaska Baseline Erosion Assessment: Study Findings and Technical Report, U.S. Army Corps of Engineers Alaska District, 65 p. http://www.poa.usace.army. mil/Library/Reports-and-Studies/Alaska-BaselineErosion-Assessments/

---2017, Wave Information Studies. http://wis.usace. army. mil/hindcasts.html?dmn=alaska

U.S. General Accounting Office changed to U.S. Government Accountability Office (GAO), December 2003, Alaska native Villages: Most are Affected by Flooding and Erosion, but Few Qualify for Federal Assistance: U.S. General Accounting Office, GAO-04-142, 91 p. https://www.gao.gov/ products/GAO-04-142

U.S. Government Accountability Office (GAO), June 2009, Alaska Native Villages: Limited Progress has been made on Relocating Villages Threatened by Flooding and Erosion: U.S. Government Accountability Office, GAO-09-551, 53 p. https:// www.gao.gov/products/GAO-09-551

U.S. Geological Survey (USGS), 1947, National Map Accuracy Standards: U.S. Geological Survey. https:// nationalmap.gov/standards/nmas.html

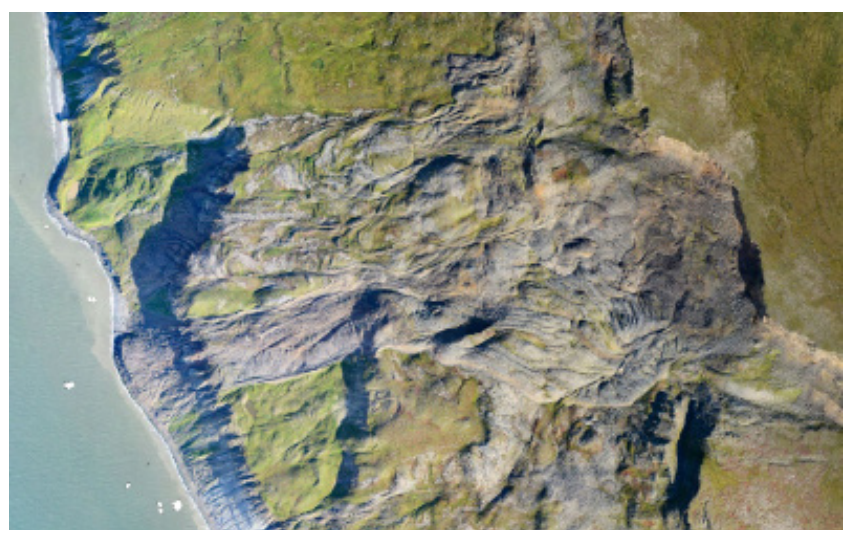

